Atmos. Chem. Phys., 17, 13783-13800, 2017

https://doi.org/10.5194/acp-17-13783-2017

(c) Author(s) 2017. This work is distributed under

the Creative Commons Attribution 3.0 License.

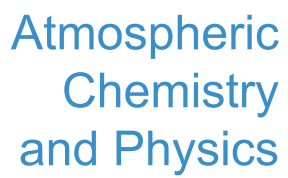

(c) (P)

\title{
Features in air ions measured by an air ion spectrometer (AIS) at Dome C
}

\author{
Xuemeng Chen $^{1}$, Aki Virkkula ${ }^{1,2}$, Veli-Matti Kerminen ${ }^{1}$, Hanna E. Manninen ${ }^{1,3}$, Maurizio Busetto ${ }^{4}$, \\ Christian Lanconelli ${ }^{4}$, Angelo Lupi ${ }^{4}$, Vito Vitale ${ }^{4}$, Massimo Del Guasta ${ }^{5}$, Paolo Grigioni ${ }^{6}$, Riikka Väänänen ${ }^{1}$, \\ Ella-Maria Duplissy ${ }^{1}$, Tuukka Petäjä ${ }^{1}$, and Markku Kulmala ${ }^{1}$ \\ ${ }^{1}$ Department of Physics, University of Helsinki, P.O. Box 64, 00014 Helsinki, Finland \\ ${ }^{2}$ Finnish Meteorological Institute, Air Quality Research, P.O. Box 503, 00101 Helsinki, Finland \\ ${ }^{3}$ CERN, 1211 Geneva, Switzerland \\ ${ }^{4}$ Institute of Atmospheric Sciences and Climate, Italian National Research Council, 40129 Bologna, Italy \\ ${ }^{5}$ Istituto Nazionale di Ottica, INO-CNR, 50019 Sesto Fiorentino (FI), Italy \\ ${ }^{6}$ ENEA Laboratory for Observations and Analyses of Earth and Climate, C.R. Casaccia, 00123 S. Maria \\ di Galeria (RM), Italy
}

Correspondence to: Xuemeng Chen (xuemeng.chen@ @elsinki.fi)

Received: 4 April 2017 - Discussion started: 20 April 2017

Revised: 25 September 2017 - Accepted: 4 October 2017 - Published: 20 November 2017

\begin{abstract}
An air ion spectrometer (AIS) was deployed for the first time at the Concordia station at Dome C $\left(75^{\circ} 06^{\prime} \mathrm{S}\right.$, $123^{\circ} 23^{\prime} \mathrm{E} ; 3220 \mathrm{ma}$ a.s.l.), Antarctica during the period 22 December 2010-16 November 2011 for measuring the number size distribution of air ions. In this work, we present results obtained from this air ion data set together with aerosol particle and meteorological data. The main processes that modify the number size distribution of air ions during the measurement period at this high-altitude site included new particle formation (NPF, observed on 85 days), wind-induced ion formation (observed on 36 days), and ion production and loss associated with cloud/fog formation (observed on 2 days). For the subset of days when none of these processes seemed to operate, the concentrations of cluster ions $(0.9-1.9 \mathrm{~nm})$ exhibited a clear seasonality, with high concentrations in the warm months and low concentrations in the cold. Compared to event-free days, days with NPF were observed with higher cluster ion concentrations. A number of NPF events were observed with restricted growth below $10 \mathrm{~nm}$, which were termed as suppressed NPF. There was another distinct feature, namely a simultaneous presence of two or three separate NPF and subsequent growth events, which were named as multi-mode NPF events. Growth rates (GRs) were determined using two methods: the appearance time method and the mode fitting method. The former method
\end{abstract}

seemed to have advantages in characterizing NPF events with a fast GR, whereas the latter method is more suitable when the GR was slow. The formation rate of $2 \mathrm{~nm}$ positive ions $\left(J_{2}^{+}\right)$was calculated for all the NPF events for which a GR in the $2-3 \mathrm{~nm}$ size range could be determined. On average, $J_{2}^{+}$was about $0.014 \mathrm{~cm}^{-3} \mathrm{~s}^{-1}$. The ion production in relation to cloud/fog formation in the size range of $8-42 \mathrm{~nm}$ seemed to be a unique feature at Dome $\mathrm{C}$, which has not been reported elsewhere. These ions may, however, either be multiply charged particles but detected as singly charged in the AIS, or be produced inside the instrument, due to the breakage of cloud condensation nuclei ( $\mathrm{CCN})$, possibly related to the instrumental behaviour under the extremely cold condition. For the wind-induced ion formation, our observations suggest that the ions originated more likely from atmospheric nucleation of vapours released from the snow than from mechanical charging of shattered snow flakes and ice crystals.

\section{Introduction}

Air ions, also known as atmospheric ions, are electric charge carriers in the atmosphere, ranging from primary ions (most have a mobility diameter smaller than $0.8-1 \mathrm{~nm}$ ) to charged aerosol particles (with a mobility diameter up to several hun- 
dred nanometres) (e.g. Harrison and Tammet, 2008; Hirsikko et al., 2011; Chen et al., 2016). Scientific interest in air ions has persisted for over a century. Air ions have a primary role in the discipline of atmospheric electricity, because their motion in the atmosphere is integral to the air conductivity (Wilson, 1924; Israël, 1970; Tinsley, 2008). Air ions have also raised the interest of aerosol scientists because of their participation in atmospheric aerosol formation and thus they have influence on air quality, human health, and climate (Gunn, 1954; Bricard et al., 1968; Hõrrak et al., 1998; Yu and Turco, 2008; Manninen et al., 2010; Waring and Siegel, 2011).

Upon the ionization of air molecules by ionizing radiation, electric charges are created. After undergoing a series of chemical and dynamic processes with trace gases and preexisting aerosol particles, electric charges that survive the initial recombination and other loss mechanisms are stabilized in the form of charged aerosol particles (Chen et al., 2016). Charged nanoparticles in the mobility size range of $1.7-7 \mathrm{~nm}$ are typically observed during new particle formation (NPF) events (Manninen et al., 2009; Hirsikko et al., 2011; Leino et al., 2016). NPF is an important source of atmospheric aerosol particles (Kulmala et al., 2004; Poschl, 2005 ) and, under favourable conditions, of cloud condensation nuclei (CCN; Kerminen et al., 2012; Dunne et al., 2016). In this way, aerosol particles originating from NPF have a potential to influence many cloud properties and thus climate (Boucher et al., 2013; Dunne et al., 2016).

Carslaw et al. (2013) suggested that aerosol-related uncertainties in global models could be best reduced through the study of natural aerosols in environments with negligible anthropogenic influence. Antarctica is such an environment. Long-term time series of particle number concentrations have been published both from the coastal Antarctica, including the Neumayer station (Weller et al., 2011), and from the upper plateau including the South Pole (e.g. Samson et al., 1990). Number size distributions of aerosol particles have been measured during short-term campaigns, mainly at coastal stations (e.g. Ito, 1993; Koponen et al., 2003; Virkkula et al., 2007; Asmi et al., 2010; Pant et al., 2011; Belosi et al., 2012; Kyrö et al., 2013; Weller et al., 2015), but also on the upper plateau at the South Pole (e.g. Park et al., 2004). Hara et al. (2011) presented particle number size distributions measured on the coast of Queen Maud Land at the Japanese station Syowa in the period 2003-2005. At the Norwegian Troll station in the inner region of Queen Maud Land, particle number size distributions in the size range 30$800 \mathrm{~nm}$ have been measured over several years (Fiebig et al., 2014). Järvinen et al. (2013) presented a 2-year record of particle number size distributions in the size range of 10 $600 \mathrm{~nm}$ measured at the Italian-French Concordia station at Dome $\mathrm{C}$ on the upper Antarctic Plateau, and observed clear signs of atmospheric NPF. However, since their measurement size range started at $10 \mathrm{~nm}$ particle diameter, there was no information on the initial step of the NPF, which is expected to take place at diameters below $2 \mathrm{~nm}$ (Kulmala et al., 2013).
In particular, the question of the role of air ions in NPF remained open. Air ion number size distributions in the size range from $<1 \mathrm{~nm}$ up to about $40 \mathrm{~nm}$ have been measured at Aboa in the coastal Antarctica during several summer campaigns (Virkkula et al., 2007; Asmi et al., 2010; Kyrö et al., 2013), but not on the upper plateau. The high altitude of Dome $\mathrm{C}$ means that the Concordia station is more exposed to cosmic radiation than the coastal sites in Antarctica. Also, stronger cosmic ray ionization can be expected at polar regions than at mid-latitudes (Kazil et al., 2006; Bazilevskaya et al., 2008). However, the inland location of Dome C represents a pristine environment with very limited source of vapours essential for clustering and subsequent nanoparticle formation. Therefore, it is worthwhile to investigate the synergic impact of high cosmic-ray ionization and low precursor vapours on the properties of air ions at this Antarctic site.

In this work, we present a first set of results on air ion observation at Dome C. Our aims are to characterize the key features of air ions at this Antarctic site, including the seasonality of their concentrations, and to analyse the variability of air ions in relation to NPF. Previously, particle growth during NPF processes has been studied in terms of growth rates (GRs) using two methods: the appearance time method (Lehtipalo et al., 2014) and the mode-fitting method (Dal Maso et al., 2005). Here we compare GRs determined using these two methods.

\section{Methods}

The analyses in this work were based on ambient data collected from the Concordia station $\left(75^{\circ} 06^{\prime} \mathrm{S}, 123^{\circ} 23^{\prime} \mathrm{E}\right)$ at Dome C in Antarctica during 22 December 2010-16 November 2011. The station is located on the Antarctic Plateau at an altitude of $3220 \mathrm{~m}$ a.s.l. and a minimum distance of $1100 \mathrm{~km}$ from the coastline (Becagli et al., 2012). Measurements were taken at the same sampling site used by Järvinen et al. (2013) and Becagli et al. (2012), located upwind in the direction of the prevailing wind at a distance of about $1 \mathrm{~km}$ southwest of the main station buildings. The northeastern direction is therefore considered as the contaminated sector $\left(10-90^{\circ}\right)$, due to local emissions from diesel generators and motor vehicles. All the data are presented in UTC.

\subsection{Air ion and total aerosol particle measurements}

\subsubsection{Air ion measurement}

The number size distribution of air ions was measured with an air ion spectrometer (AIS) during the campaign period. The AIS employs two cylindrical multi-channel aspirationtype analysers and a high sample flowrate $\left(60 \mathrm{~L} \mathrm{~min}^{-1}\right)$. Such design enables it to measure negative and positive ions simultaneously down to sizes of below $1 \mathrm{~nm}$ (Mirme et al., 2007).

The air sampled in the AIS is split into two equal streams. On the way to the analyser, each stream passes through 
a sample preconditioner, i.e. a corona charger coupled with an electrical filter. Sample preconditioners are turned on only during the measurement of background signals, where corona chargers produce charger ions of an opposite polarity to the subsequent analysers, so that clusters and particles in each sample stream are either neutralized or assigned an opposite polarity to the analyser and therefore generate no signal in the detection system. During the campaign, each AIS measurement cycle was composed of 1 min background probing and $4 \mathrm{~min}$ ambient sampling. Preconditioners are turned off for ambient sampling. Sample streams pass directly into the respective analysers, where air ions are segregated based on their electrical mobility into different channels. The analyser used in the AIS is a variant of the differential mobility analyser (DMA). Unlike common cylindrical DMA, in which ions are collected at the inner electrode and, via altering the voltage applied on the electrodes, ions of different mobility are measured (Hinds, 1999), the outer electrode in the AIS analyser serves the collecting role and ions of different mobility are collected simultaneously by different channels. The operation of the AIS analyser is based on electrical repulsion. The sample flow is introduced near the inner electrode and sheath flow near the outer one. The outer electrode of the AIS analyser is divided into 21 insulated sections, each of which is connected to an electrometer as the detector. Coupling the outer electrode design with a specially shaped inner electrode, which comprises several cylindrical sections biased at different potentials, the analyser is able to perform a concurrent classification of ions into the 21 measuring channels. More detailed technical descriptions of the instrument are presented by Mirme et al. (2007) and Mirme and Mirme (2013).

The AIS assumes the normal temperature and pressure (NTP) condition and has a total sample flowrate of $60 \mathrm{~L} \mathrm{~min}^{-1}$ and a sheath flowrate of $60 \mathrm{~L} \mathrm{~min}^{-1}$ in each analyser at NTP. A single blower controls the whole flow system. Although sample, sheath and total exhaust flowrates are monitored by Venturi flowmeters to balance the flow system in the AIS, only the total exhaust flowrate, equivalent to the total sample flowrate, is recorded. Owing to the distinct ambient condition at Dome $\mathrm{C}$ in relation to NTP, a flow correction was applied to the recorded data to retrieve the actual number concentration of ions. In a Venturi system, the volumetric flowrate $(Q)$ is expressed as

$$
Q=C \sqrt{\frac{2 \Delta P}{\rho}} \frac{A_{a}}{\sqrt{\left(\frac{A_{a}}{A_{b}}\right)^{2}-1}},
$$

where $C$ is the discharge coefficient which takes into account the viscosity of fluids, $\Delta P$ is the pressure difference across the Venturi tube, $\rho$ is the density of the fluid, and $A_{a}$ and $A_{b}$ are the cross sections of the Venturi tube at the two locations between which the pressure difference is determined. In the case of air, the density can be derived from the ideal gas law

$\rho=\frac{P M}{R T}$,

where $P$ is pressure in pascal, $T$ is temperature in kelvin, $R$ is the gas constant, and $M$ is the molar mass of air. Since the AIS measurement is based on the NTP assumption, the corrected sample flowrate $\left(Q_{\mathrm{s} \text {, cor }}\right)$ can be obtained by adding an additional multiplier, $\sqrt{\frac{T_{\text {atm }}}{P_{\text {atm }}} \frac{P_{\mathrm{NTP}}}{T_{\mathrm{NTP}}}}$, to Eq. (1) as follows:

$$
Q_{\mathrm{s}, \text { cor }}=C \sqrt{2 \Delta P} \sqrt{\frac{R T_{\mathrm{NTP}}}{P_{\mathrm{NTP}} M}} \frac{A_{a}}{\sqrt{\left(\frac{A_{a}}{A_{b}}\right)^{2}-1}} \sqrt{\frac{T_{\mathrm{atm}}}{P_{\mathrm{atm}}} \frac{P_{\mathrm{NTP}}}{T_{\mathrm{NTP}}}},
$$

where $P_{\mathrm{NTP}}$ and $T_{\mathrm{NTP}}$ are pressure and temperature at the NTP condition, and $P_{\text {atm }}$ and $T_{\text {atm }}$ are at ambient atmospheric conditions. Equation (3) can be simplified to the following form:

$Q_{\mathrm{s}, \text { cor }}=Q_{\mathrm{s}, \text { meas }} \sqrt{\frac{T}{P} \frac{P_{\mathrm{NTP}}}{T_{\mathrm{NTP}}}}$,

where $Q_{\mathrm{s} \text {, meas }}$ denotes the recorded sample flowrate by the AIS. Then, the number concentration of ions measured in each mobility range $\left(N_{i}\right)$ is corrected by

$N_{i, \text { cor }}=N_{i, \text { meas }} \cdot \frac{Q_{\mathrm{s}, \text { meas }}}{Q_{\mathrm{s}, \text { cor }}}$.

In addition to the number concentration, the flowrates in the AIS influence the upper and lower limits of mobility ranges (Mirme et al., 2010; Mirme and Mirme, 2013). The lower and upper limiting mobility are proportional to the sheath flowrate $\left(Q_{\mathrm{sh}}\right)$ and the sum of sample and sheath flowrates, respectively. Therefore, the corrected lower and upper limiting mobility can be expressed as

$$
\begin{aligned}
& Z_{i, \mathrm{~L}, \mathrm{cor}}=Z_{i, \mathrm{~L}, \text { meas }} \cdot \frac{Q_{\mathrm{sh}, \text { cor }}}{Q_{\mathrm{sh}, \text { meas }}} \quad \text { and } \\
& Z_{i, \mathrm{U} \text {,cor }}=Z_{i, \mathrm{U} \text {,meas }} \cdot \frac{Q_{\mathrm{sh} \text {, cor }}+Q_{\mathrm{s}, \text { cor }}}{Q_{\mathrm{sh} \text {, meas }}+Q_{\mathrm{s} \text {, meas }}},
\end{aligned}
$$

where $Z_{i, \mathrm{~L}}$ and $Z_{i, \mathrm{U}}$ represent lower and upper limiting mobility in the mobility range, $i$.

In this work, to be comparable with particle data, air ion data are presented in Millikan mobility diameters. The conversion of electrical mobility to sizes is based on the StokesMillikan equation (e.g. Hinds, 1999), using measured ambient temperature and pressure. After the flow correction, the AIS has a measurable mobility size range of $0.9-48 \mathrm{~nm}$. The deployed AIS had a separate $30 \mathrm{~cm}$ long inlet that extended outside the measurement cabin. The inlet tube had an inner diameter of $16 \mathrm{~mm}$. However, since we had no measurement of the temperature profile of the inlet, a correction for the inlet diffusional loss is not feasible. Therefore, we report the 


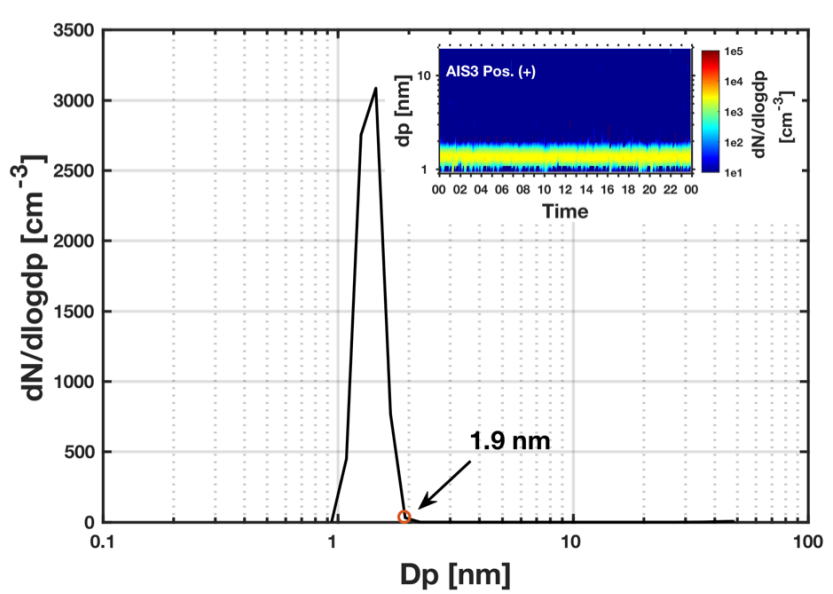

Figure 1. The median size distribution of positive ions measured by the AIS on an event-free day (16 January 2011). The measured number size distribution of this day is shown in the contour plot.

number size distribution data of air ions without the inlet diffusional loss correction.

The primary feature of an ambient AIS spectrum contains a persistent band of high ion concentrations at lowest sizes (Fig. 1), which is typically known as the cluster ion band. The upper boundary of this band typically lies at around $1.7 \mathrm{~nm}$ in the mobility diameter $(\sim 1.3 \mathrm{~nm}$ in the mass diameter; Mirme et al., 2007) under mid-latitude ambient conditions, representing critical cluster sizes (Kulmala et al., 2013; Chen et al., 2016). After applying the flow and ambient condition correction to the AIS data, the cluster ion size range at Dome $\mathrm{C}$ was found to be between 0.9 and $1.9 \mathrm{~nm}$ in the positive polarity (Fig. 1). However, the upper boundary of the cluster size range in the recorded negative AIS spectra was shifted down to around $1 \mathrm{~nm}$ (Fig. S1 in the Supplement), likely caused by the establishment of an ill-shaped electric field inside the analyser due to the malfunctioning of grounding or insulation. Such an anomaly is indicative of a low reliability of the negative ion data. Thus, only positive ion data from the AIS measurement are reported in this work.

\subsubsection{Total aerosol particle measurement}

A differential mobility particle sizer (DMPS), the same used by Järvinen et al. (2013), was responsible for recording the number size information of total aerosol particles. The DMPS classifies particles of mobility sizes between 9 and $550 \mathrm{~nm}$. It consists mainly of a medium-size Hauke-type DMA for classifying particles and a TSI 3010 condensation particle counter (CPC) for detection. Prior to the classifying and detecting sections, the sampled air passes through a bipolar radioactive charger (Ni-63), where aerosol particles in the sample attain a Boltzmann equilibrium charge distribution. These aerosol particles then enter the DMA. Particles of different electrical mobility are selected from the sample by changing the high voltage applied on the DMA inner electrode step-wisely. The mobility-segregated particles are subsequently grown by vapour condensation and detected optically in the CPC. Each measurement cycle takes $10 \mathrm{~min}$. The number size distribution of the measured aerosol particles was derived from the recorded mobility distribution via an inversion procedure described in detail by Aalto et al. (2001). The sizes of aerosol particles are presented in Millikan mobility diameters. Hereafter, unless otherwise specified, the particle and ion sizes refer to their Millikan mobility diameters.

\subsection{Meteorological and lidar data}

The ambient air temperature $(T)$, relative humidity (RH), wind speed (WS), and wind direction (WD) data were from the routine meteorological observation records at Station Concordia as part of the IPEV/PNRA Project - a collaborative project between "Programma Nazionale di Ricerche in Antartide" (PNRA) and Institut Polaire Français Paul-Emile Victor (IPEV) (www.climantartide.it).

An automatic depolarization lidar $(532 \mathrm{~nm})$ has operated at Dome C since 2008 (http://lidarmax.altervista.org/englidar/ _Antarctic\%20LIDAR.php). The lidar is sensitive to large aerosols and cloud particles, whose presence can be detected from a few metres above ground to $7000 \mathrm{~m}$. The discrimination between liquid and solid relies on the aerosol-induced depolarization of linearly polarized laser light.

\subsection{Derived quantities}

To assist our analyses, GRs, condensation sinks (CS), and formation rates of ions were determined from the measured air ion and total aerosol particle spectra. The GR characterizes how rapidly particles enlarge in size due to condensational growth and coagulation, which typically has a unit of $\mathrm{nmh}^{-1}$ (Dal Maso et al., 2005; Kulmala et al., 2012). The CS describes the loss rate of condensable vapours onto aerosol particles and is expressed in $\mathrm{s}^{-1}$ (Pirjola et al., 1998; Dal Maso et al., 2002). The formation rate of ions quantifies the rate at which ions in a certain size range are formed and has a unit of $\mathrm{cm}^{-3} \mathrm{~s}^{-1}$ (Nieminen et al., 2011; Kulmala et al., 2012).

\subsubsection{GR determination}

The concentration of ions/aerosol particles evolves in both time and particle size. We used two approaches in determining GRs: the mode-fitting method (Dal Maso et al., 2005) and the appearance time method (Lehtipalo et al., 2014). The mode-fitting method follows the concentration change in the time dimension and the appearance time method follows the change in the size dimension.

In the mode-fitting method, at each time stamp of the measurement, the representative size of the aerosol population is determined by fitting a normal distribution to the measured 
concentration distribution along the logarithm of sizes with a base of 10 . The mode of the fitted curve is transcribed back to linear scale and taken as the representative size of the particle population measured at this moment (a more detailed description of the method has been presented by Dal Maso et al., 2015). In contrast, in the appearance time method, for each size (the geometric mean size of a measurement size bin), one determines the time (the appearance time) at which the particle population is considered to reach this size, based on the measured concentration evolution in time (Lehtipalo et al., 2014). This procedure is repeated for each measurement size bin. In this study, we defined the moment at which the concentration rises to $75 \%$ of the maximum as the appearance time for each size. The GR was then calculated as the slope of a linear fit to the size data as a function of time. In addition, we also determined the instantaneous GR $(\mathrm{d} d p / \mathrm{d} t)$ as the change in sizes within the interval of two adjacent time stamps to support the analysis of the GR dependence on sizes.

\subsubsection{CS determination}

Sulfuric acid is a key chemical species in forming aerosol particles in the ambient air (Kulmala et al., 2014). We determined CS for sulfuric acid vapours from the number size distribution measured by the DMPS, based on the method described by Pirjola et al. (1998) and Dal Maso et al. (2002), using the following equation:

$\mathrm{CS}=2 \pi D \int d_{\mathrm{p}} \beta\left(d_{\mathrm{p}}\right) n\left(d_{\mathrm{p}}\right) \mathrm{d} d_{\mathrm{p}}$.

Here $D$ is the diffusion coefficient of condensing vapour molecules, $d_{\mathrm{p}}$ is the diameter of aerosol particles, $n$ is the concentration, and $\beta$ is a transitional correction factor (Fuchs and Sutugin, 1971), which is a function of the mass accommodation coefficient $(\alpha)$ and Knudsen number $(K n)$. In most applications, $\alpha$ is assumed to be unity while $K n$ can be connected to $D$ via the mean free path of vapour molecules $\left(\lambda_{\mathrm{v}}\right)$ using the mean free-path theory (Mason and McDaniel, 1988; Pirjola et al., 1998).

The diffusion coefficient of vapour molecules is determined using the Fuller's model (Poling et al., 2004; Tang et al., 2014), which describes a binary gas system of species A diffusing in $\mathrm{B}$ :

$D=\frac{0.00143 \cdot T^{1.75}}{\left[P / 10^{5}: \text { bar }\right] \cdot M_{\mathrm{AB}}^{1 / 2}\left[\left(\Sigma_{\mathrm{v}}\right)_{\mathrm{A}}^{1 / 3}+\left(\Sigma_{\mathrm{v}}\right)_{\mathrm{B}}^{1 / 3}\right]^{2}}$,

with $\quad M_{\mathrm{AB}}=\frac{2}{1 / M_{\mathrm{A}}+1 / M_{\mathrm{B}}}$

Here, $\left(\Sigma_{\mathrm{V}}\right)_{\mathrm{A}}$ and $\left(\Sigma_{\mathrm{V}}\right)_{\mathrm{B}}$ are the diffusion volumes of species $\mathrm{A}$ and $\mathrm{B}$, respectively, and $M_{\mathrm{A}}$ and $M_{\mathrm{B}}$ are the corresponding molar masses. For the system of sulfuric acid diffusing in air, $\Sigma_{v, \mathrm{H}_{2} \mathrm{SO}_{4}}=51.96$ and $\Sigma_{v \text {, air }}=19.7$. The measured ambient temperature and pressure were used in the CS determination.

\subsubsection{Formation rate of $2 \mathrm{~nm}$ ions $\left(J_{2}^{ \pm}\right)$}

The formation rates of $2 \mathrm{~nm}$ ions $\left(J_{2}^{ \pm}\right)$was determined based on the following equation:

$J_{2}^{ \pm}=\frac{\mathrm{d} n_{2-3}^{ \pm}}{\mathrm{d} t}+\mathrm{CoagS}_{2} n_{2-3}^{ \pm}+\frac{\mathrm{GR}_{2-3}}{1 \mathrm{~nm}} n_{2-3}^{ \pm}+\alpha n_{2-3}^{ \pm^{2}}$,

where $n_{2-3}^{ \pm}$is the ion concentration in the 2-3 nm size range, $\mathrm{GR}_{2-3}$ is the GR of $2-3 \mathrm{~nm}$ ions, and $\alpha$ is the ion-ion recombination coefficient $\left(\alpha=1.6 \times 10^{-6} \mathrm{~cm}^{3} \mathrm{~s}^{-1}\right)$. CoagS stands for the coagulation sink for $2 \mathrm{~nm}$ ions and it was determined using particle data measured by the DMPS based on the method described by Kulmala et al. (2001). Owing to the malfunction of the negative analyser in our AIS, the ion formation rates in this study were determined only for the positive polarity, based on the assumption that the negative ion concentration is equal to the positive ion concentration.

\section{Results and discussions}

\subsection{Overview of features observed in air ions}

During the campaign period (330 days in total), there were 287 days with valid air ion measurements, i.e. valid air ion data were collected on nearly $87 \%$ of the measurement days. We were able to identify NPF, wind-induced ion formation, and cloud activation events from the valid measurements. Altogether, NPF events were observed on 32 days, windinduced ion formations on 36 days, and cloud activations on 7 days with two certain cases. For the NPF events, 20 cases were classified as suppressed NPF events, which were characterized by no clear particle growth beyond $10 \mathrm{~nm}$. Cases with two or more separate, yet simultaneous, NPF events with subsequent growth, i.e. multi-mode NPF events, were seen on 12 NPF days. Additionally, 85 days were recognized as event-free days, during which no above-mentioned events, contamination, or other unexplainable processes disturbing the cluster ion band (0.9-1.9 nm) were observed.

A clear seasonality was found on these event-free days in the cluster ion concentration (Fig. 2a). The cluster ion concentration was highest during the warm months, with a maximum in February. The median cluster ion concentration was typically below $100 \mathrm{~cm}^{-3}$ during the winter. This seasonality is related to variations in the natural ionizing radiation, which produces initial charge carriers via the ionization of air molecules, as well as to the availability of vapours capable of forming cluster ions (Chen et al., 2016). The variability in the ionizing radiation originates, in general, from changes in the atmospheric radon concentration, terrestrial gamma, and cosmic radiation (Chen et al., 2016). Owing to the presence of the thick ice and snowpack (over $3000 \mathrm{~m}$ in depth; Augustin et al., 2004), the contribution of radon exhalation or terrestrial gamma emissions from ground at Dome $\mathrm{C}$ to the ionization of air molecules can be neglected. Also, atmo- 

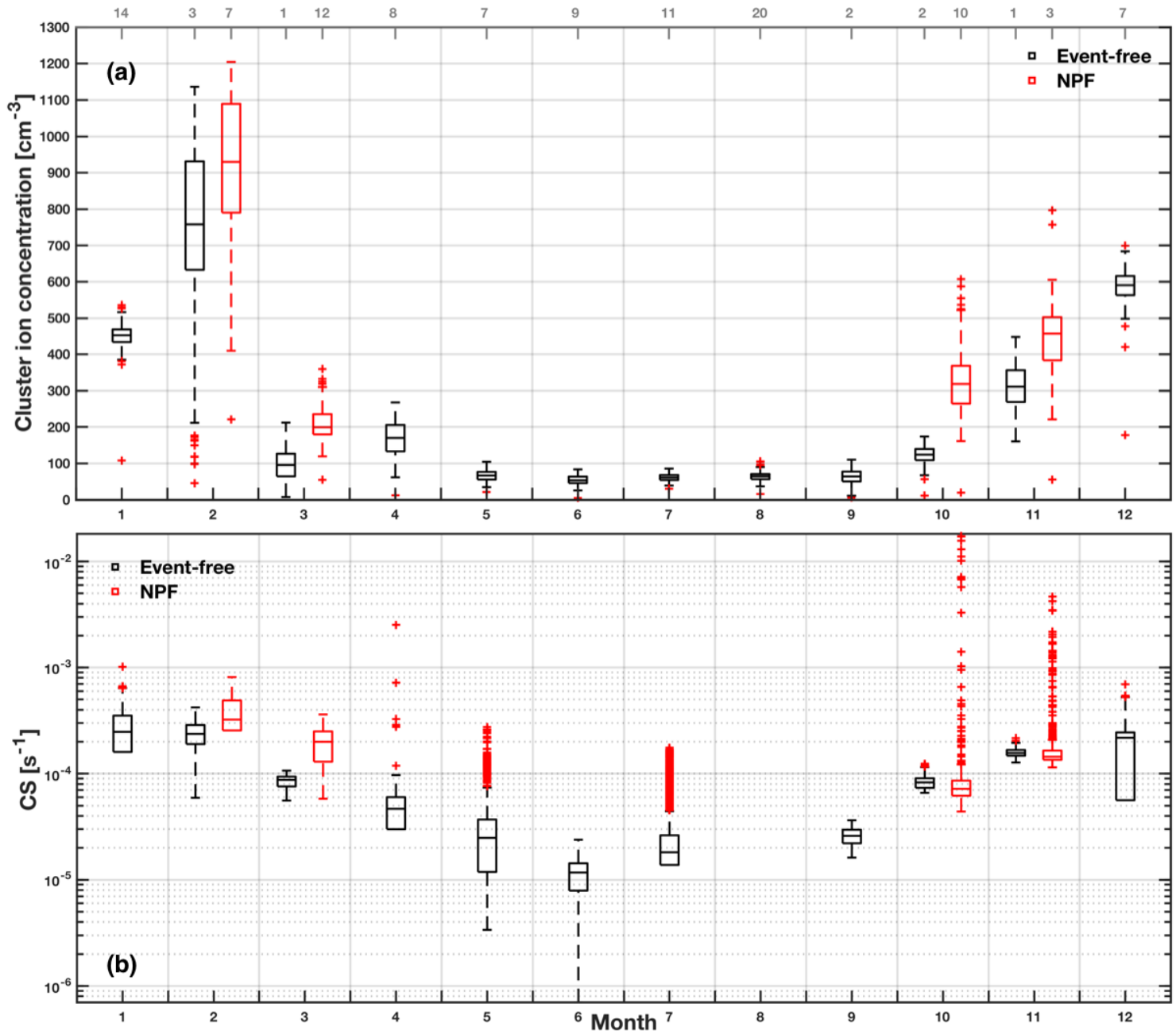

Figure 2. Seasonality in the median (a) cluster ion (0.9-1.9 nm) concentration and (b) condensation sink (CS). Tops and bottoms of the boxes are the 75th and 25th percentiles of the median daily values in 10 min time resolution, with bars in the middle showing the 50th percentiles. Whiskers represent spans of the interquartile ranges multiplied by 1.5. Cluster ion concentrations or CS on NPF days shown in red and on event-free days in black. Event-free conditions were restricted to days on which there was no NPF, cloud activation, wind-induced events, or contamination as well as other anomalies altering the ion concentration in the cluster band. The numbers of days classified as either event-free or NPF are displayed at the top of panel (a) in grey. No CS was obtained in August due to the lack of measured temperature and pressure data from the station database.

spheric radon emitted from the coastal areas or other remote regions may hardly reach Dome $\mathrm{C}$ by wind transportation. Therefore, the only major ionization source of air molecules comes from cosmic radiation. The cosmic ray intensity is mainly modulated by the solar activity and therefore can be considered invariable in the short term. Muons are the main cosmic ray component responsible for the ionization in the lower atmosphere (Goldhagen, 2000). The intensity of the muon flux in Antarctica has been found to have a weak seasonality and to be related to the stratospheric temperature, being low in winter and high in summer, and the temperature modulation has been reported to be $\pm 8 \%$ on an annual basis (IceCube Collaboration, 2011). Although the seasonal cycle in the cluster ion concentration corresponded to the seasonality in the muon flux, the influence of the variation in the ionizing radiation alone is insufficient to account for the difference of more than $30 \%$ in the cluster ion concentration between summer and winter (Fig. 2a). Thus, most probably the low winter cluster ion concentration was additionally affected by the limited source of vapours that can participate in cluster ion formation due to the inhibited photochemistry under the reign of polar-night darkness. The development of the planetary boundary layer may additionally influence the concentration of cluster ions by imposing either a dilution or concentration effect. The longer day length in February than in March or October may result in the development of a deeper mixed layer, which could dilute the cluster ions within the mixing volume. However, the high- 
est cluster ion concentration was found in February. Also, polar nights would cause the formation of only a very shallow and stable boundary layer in winter months. The mixing volume in winter is therefore expected to be much smaller than in other seasons, but no concentration effect on cluster ion concentration can be identified. Consequently, even if the seasonal change of boundary layer heights has an influence on the seasonality in cluster ion concentrations, this effect is likely to be minor.

The daily-median cluster ion concentration at Dome C was observed to be higher on NPF event days compared with event-free days. A similar phenomenon was also seen in a boreal forest environment at SMEAR II station in southern Finland (Fig. S2). Such a connection between cluster ion concentrations and NPF occurrences may imply that compared with event-free days, NPF event days probably had higher concentrations of vapours that are able to contribute to both cluster ion formation and NPF. In the Antarctic autumn (February and March), the value of CS tended to be higher on NPF days compared with event-free days (Fig. 2b). Since a large CS is indicative of a higher atmospheric sink for low-volatility vapours, this observation suggests a particularly strong source rate of such vapours during this time of the year, especially on NPF days. Interestingly, the opposite pattern in CS was seen in the Antarctic spring (October and November, Fig. 2b).

\subsection{NPF and growth}

\subsubsection{NPF events}

One of the major features observed in the AIS spectra at Dome $\mathrm{C}$ was the process of NPF and subsequent growth of newly formed charged clusters/particles. The smooth growth that lasts for several hours can imply a homogeneous condition in the sampled air (Hirsikko et al., 2007; Manninen et al., 2010). Seven clear NPF events were seen on consecutive days during the period 9-15 March 2011, with the initial step traceable down to the cluster ion band (Fig. 3b). All these NPF events occurred during westerly winds, apart from the first one on 9 March (Fig. 3e). This NPF event was associated with winds from the contaminated sector $\left(10-90^{\circ}\right)$ and possibly affected by the diesel generator of the station and motor vehicle pathways (Järvinen et al., 2013). These NPF events occurred after sunrise between about 00:00 and 06:00 UTC (between 08:00 and 14:00 in the local UTC + 8:00 time zone), which is in line with the proposed importance of photochemistry in NPF events and particle growths (Kulmala and Kerminen, 2008; Ehn et al., 2014; Kulmala et al., 2014). Except for the weak NPF event on 10 March, the newly formed particles of 9-12 March reached sizes larger than $10 \mathrm{~nm}$ and could be captured by both AIS and DMPS (Fig. 3a and $b$ ). Sudden increases in the concentration of 10-100 nm total particles corresponded to these NPF events (Fig. 3c). However, the NPF events seen during 13-15 March were re- stricted to sizes below $10 \mathrm{~nm}$ and showed no traces in the DMPS spectra (Fig. 3a and b). Consistently, no elevated concentrations were observed for particles in the size range of $10-100 \mathrm{~nm}$ for these events (Fig. 3c). Such differences result likely from the availability of vapours that sustain the growth. We could see slight concentration increases in the cluster ion size range at the time when NPF events were initiated, but no systemic features in relation to NPF events were identifiable in the total concentration of particles larger than $100 \mathrm{~nm}$ (Fig. 3c). The CS varied in a similar way to the total concentration of particles larger than $100 \mathrm{~nm}$, ranging between $10^{-4}$ and $4 \times 10^{-4} \mathrm{~s}^{-1}$, in line with the values of CS reported at Dome C during NPF events (Järvinen et al., 2013).

Figure 4 shows examples of multi-mode NPF events that were observed during 12-16 February 2011. One of them (14 to 15 February) had three concurrent NPF and growth events. The first of them was initially captured by the DMPS at around 03:00 UTC, and at a size of around $15 \mathrm{~nm}$, but it showed no clear traces in the AIS measurements before 12:00 UTC. While the particles formed during this first event were still growing in size, a second NPF event started from a size of $9 \mathrm{~nm}$ at 18:00 UTC and was detected almost simultaneously by both AIS and DMPS. About $4 \mathrm{~h}$ after the onset of the second NPF event, and during the growth stages of both the first and second events, a third NPF event was observed in the AIS starting from the cluster size range. The growth of particles originating from this last NPF event ceased at around $6 \mathrm{~nm}$ and was therefore not seen by the DMPS. A similar multi-mode NPF event was also observed on the following day, 16 February (Fig. 4). On 12 February at 06:00 UTC, a NPF event was observed by the DMPS at an initial size of $10 \mathrm{~nm}$, and the same event was observed by the AIS after around 13:00 UTC. This event lasted until the noon of 13 February. Over the consecutive 5 days of 12-16 February, a slowly growing $\left(\mathrm{GR} \approx 1.4 \mathrm{~nm} \mathrm{~h}^{-1}\right)$ population of 40 $200 \mathrm{~nm}$ particles could be observed in the background, with their initial formation traceable back to 06:00 UTC on 12 February. Interestingly, apart from the particles initiated at 10 and $40 \mathrm{~nm}$, a third mode of particles with sizes larger than $100 \mathrm{~nm}$ was recognizable on the morning of 12 February. This particle mode grew approximately from 100 to $300 \mathrm{~nm}$ during 12-13 February, and then gradually merged with the mode initiated at $40 \mathrm{~nm}$ at the end of 16 February. These multi-mode NPF events were associated with 2 times higher values of CS than the events presented in Fig. 3, owing to the presence of higher concentrations of background particles (Figs. 3c, 4c and d).

\subsubsection{GR comparisons}

The GRs determined by the appearance time method tended to be higher than those determined by the mode-fitting method (Fig. 5). This difference probably originates from the foundations that these two methods rest on. Both methods were developed to treat the measured number size dis- 


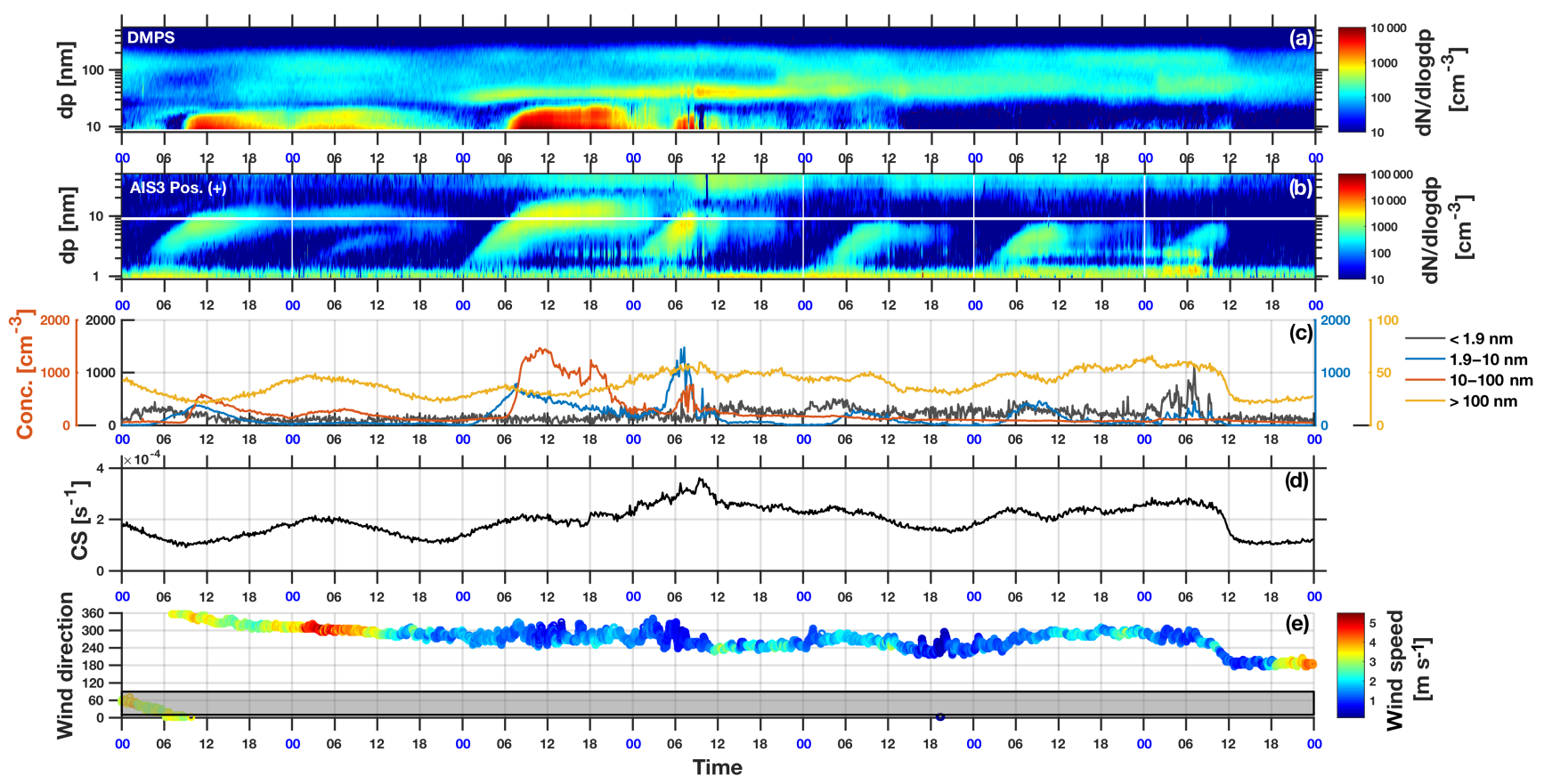

Figure 3. Consecutive NPF events observed during the period 9-15 March 2011. (a) DMPS spectra; (b) AIS positive polarity spectra; (c) ion and particle concentrations in four different size ranges: $0.9-1.9 \mathrm{~nm}$ (ions), $1.9-10 \mathrm{~nm}$ (ions), 10-100 nm (total particles), and total particles of diameters above $100 \mathrm{~nm}$; (d) CS; and (e) wind direction, colour-coded for wind speed. The white line in (b) indicates the lower limit of the DMPS size range. The grey band in (e) represents the contaminated wind sector. Data are presented in UTC.

tribution data of ions/particles that vary in time, size, and ion/particle number concentrations. The appearance time method follows the concentration change as a function of time along the particle size dimension, whereas the modefitting method tracks the concentration change as a function of particle size along the time dimension. Accordingly, the appearance time method is able to preserve the growth features related to particle size, whereas the mode-fitting method characterizes better the evolution of particle growth with time.

The NPF event that occurred on 12 March between 00:00 and 06:00 UTC had clearly two simultaneously growing modes, with corresponding particle GRs marked by $\mathrm{GR}_{6}$ and $\mathrm{GR}_{7}$ in Fig. 5a and b. For this NPF event, although higher uncertainties were associated with the GR determined by the appearance time method than with the mode-fitting method, the former method succeeded in tracking the growth following both modes while the latter failed (Fig. 5). For $\mathrm{GR}_{1}$ and $\mathrm{GR}_{4}$, both methods led to similar GR values based on linear fitting - however, with a slightly smaller uncertainty (root-mean-square error) obtained using the appearance time method. Apart from for the slow-growth cases, the appearance time method seems to present a narrower uncertainty range than the mode-fitting method.

Even though the GR is often calculated as the slope of a linear fit to the size data as a function of time (Yli-Juuti et al., 2011; Lehtipalo et al., 2014), like in Fig. 5, it is not always appropriate to express the change in sizes along time by a linear proportionality, e.g. $\mathrm{GR}_{1}$ determined by the appearance time method in Fig. $5 \mathrm{~b}$ and $\mathrm{GR}_{2}$ determined by the mode-fitting method in Fig. 5a. Alternatively, the change in sizes within the interval of two adjacent time stamps, i.e. the instantaneous GR $(\mathrm{d} d p / \mathrm{d} t)$, was used to investigate the size dependence of GR. We found that the instantaneous GR derived from the AIS measurements during the NPF events tended to increase with an increasing particle size (Fig. 6c and d). A similar feature has been reported at many other sites for the sub-20 nm size range (see Häkkinen et al., 2013, and references therein). The median instantaneous GRs given by the appearance time method were in the range of 0.5 $25 \mathrm{~nm} \mathrm{~h}^{-1}$ and by the mode-fitting method in the range of $1-$ $150 \mathrm{~nm} \mathrm{~h}^{-1}$. The reported GRs of newly formed atmospheric aerosol particles are typically below a few tens of $\mathrm{nm} \mathrm{h}^{-1}$ (Yli-Juuti et al., 2011; Järvinen et al., 2013; Wang et al., 2017). The instantaneous GRs determined using the former method fall in this range, while using the latter method resulted in larger instantaneous GRs. This feature could be ascribed to the higher uncertainties associated with the modefitting method. The mode-fitting method tracks the mode concentration corresponding to sizes based on curve fitting for each measurement cycle, and it could be that the sizes at which mode concentrations were identified differ significantly in two adjacent measurement cycles, i.e. over a short time interval. A large size difference over a small time in- 


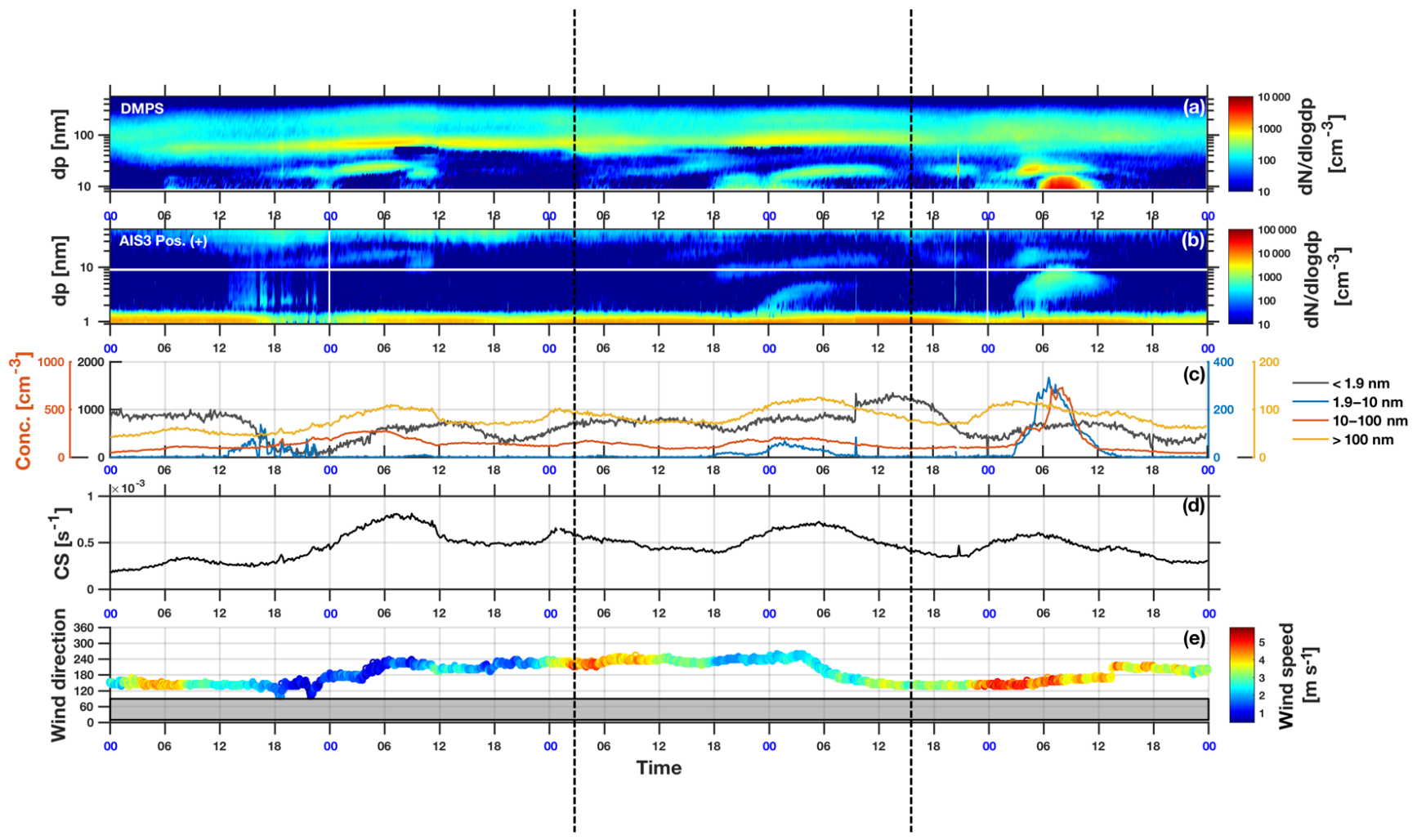

Figure 4. Consecutive multi-mode formation and growth events observed during 12-16 February 2011. (a) DMPS spectra; (b) AIS positive polarity spectra; (c) ion and particle concentrations in four different size ranges $0.9-1.9 \mathrm{~nm}$ (ions), $1.9-10 \mathrm{~nm}$ (ions), 10-100 nm (total particles), and total particles of diameters above $100 \mathrm{~nm}$; (d) CS; and (e) wind direction, colour-coded with wind speed. The white line in (b) indicates the lower limit of the DMPS size range. The grey band in (e) represents the contaminated wind sector. The two vertical dashed lines outline the three NPF which occurred on 14-15 February 2011. Data are presented in UTC.
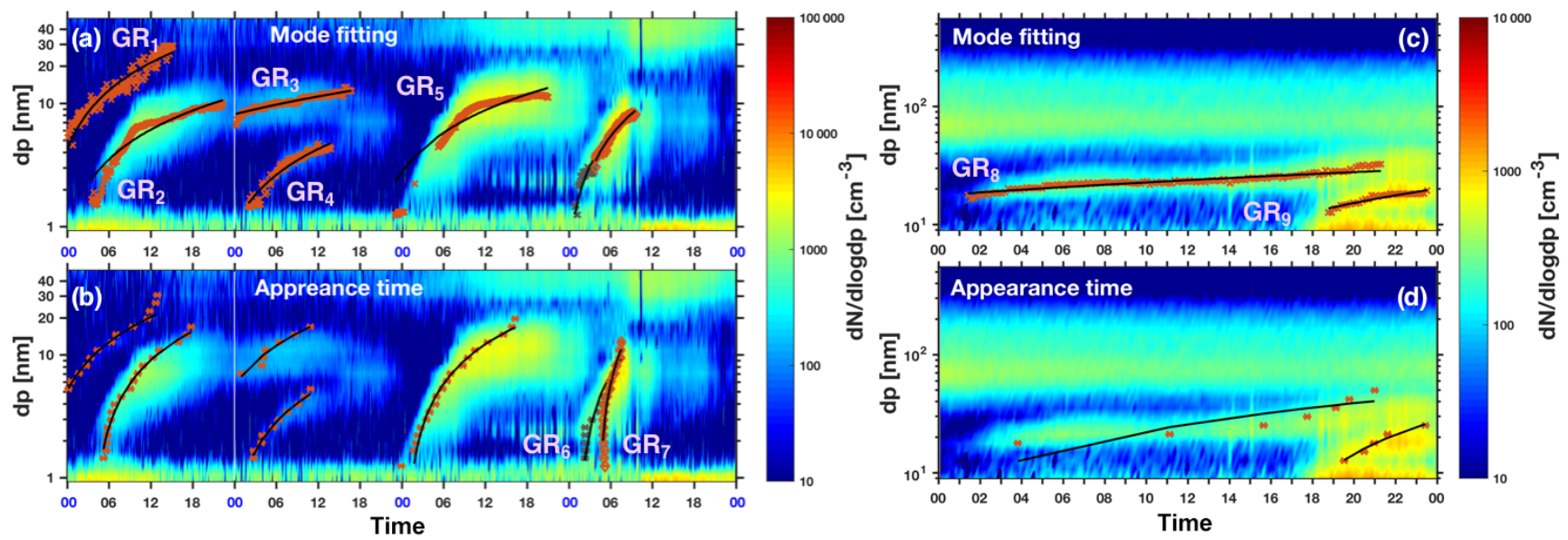

Figure 5. Comparison of GR for nine growth modes $\left(\mathrm{GR}_{i}, i=1, \ldots, 9\right.$ in the figure) determined by the mode-fitting method (a, c) and by the appearance time method (b, d), from the AIS measurement for 9-12 March 2011 (left-hand panels) and from the DMPS measurement for 25 February 2011 (right-hand panels). Growth rates estimated from linear fittings with root-mean-square errors expressed as uncertainties are shown in Table 1. The red or grey dots depict the estimated size evolution of ions/particles with respect to time determined by the mode-fitting or appearance time methods, with the linear fits to these size-time relationships shown as black lines. 

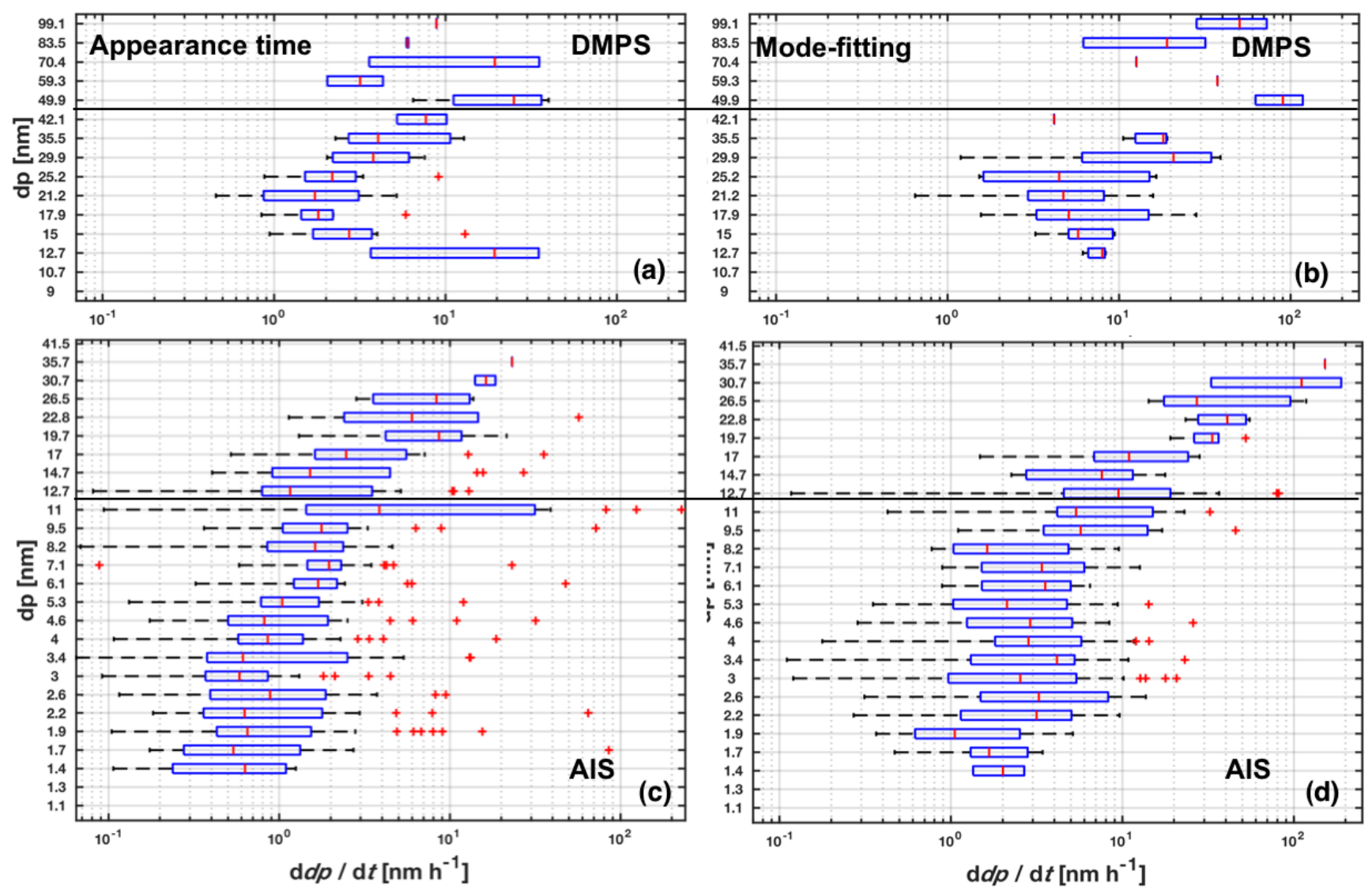

Figure 6. The GR dependence on size. Sizes are in mobility diameters and GRs of ions and particles are presented as discrete time derivatives of the change in mobility diameters $(\mathrm{d} d p / \mathrm{d} t)$. GRs of aerosol particles measured by the DMPS are shown in the upper panels (a, b), and GRs of ions measured by the AIS are shown in the lower panels $(\mathbf{c}, \mathbf{d})$. GRs in the left-hand panels $(\mathbf{a}, \mathbf{c})$ are determined using the appearance time method and those in the right-hand panels $(\mathbf{b}, \mathbf{d})$ are determined using the mode-fitting method. The solid black lines indicate the overlapping size range of the DMPS and AIS measurements. The box was drawn with 25th and 75th percentiles of GRs determined at each size, with the median indicated as a right bar inside the box. The whiskers extend to the smallest and highest GR values within 1.5 times the interquartile range at each size. GRs beyond the 1.5 times interquartile range are marked by red crosses as outliers.

terval, therefore, would lead to a huge instantaneous GR. In contrast, the appearance time method is based on looking for the time stamp, when the concentration reaches $75 \%$ of its maximum in the concentration vs. time space for each size channel of the instrument. Owing to the fact that aerosol and ion data have a higher resolution in the time dimension than in the size dimension, the appearance time method could pick up the time stamp more precisely for each size than the mode-fitting method could do the sizes for each measurement cycle. Consequently, the appearance time method presents GRs with smaller uncertainties (Fig. 5 and Table 1) and yields more representative instantaneous GRs. The instantaneous GRs derived from the DMPS measurement exhibit a rather vague pattern in connection to sizes (Fig. 6a and b); yet, a light increasing tendency might be still deducible. At large sizes in the overlapping size range (10-42 nm) of AIS and DMPS, the instantaneous GR derived from the AIS measurements tended to be larger than those from the DMPS measurements. This difference may result from the fact that the DMPS measures total particles, including both ions and neutral particles, whereas the AIS detects only charged particles. Also, the AIS measurements at sizes larger than $20 \mathrm{~nm}$ are subject to the uncertainties brought about by the detection of multiply charged particles as singly charged particles. At small sizes in the overlapping size range, the instantaneous GR derived from the DMPS exhibited a decreasing trend with increasing sizes, which, however, was not shown by the instantaneous GR derived from the AIS. This difference may again be attributed to the difference in the sampled particles targeted by the two instruments.

\subsubsection{Formation rates of $2 \mathrm{~nm}$ positive ions $\left(J_{2}^{+}\right)$}

The formation rate of $2 \mathrm{~nm}$ positive ions $\left(J_{2}^{+}\right)$was determined for 26 NPF event days, for which GRs in the $2-$ $3 \mathrm{~nm}$ size range were obtained using the appearance time method. The average value of $J_{2}^{+}$was $0.014 \mathrm{~cm}^{-3} \mathrm{~s}^{-1}$, 

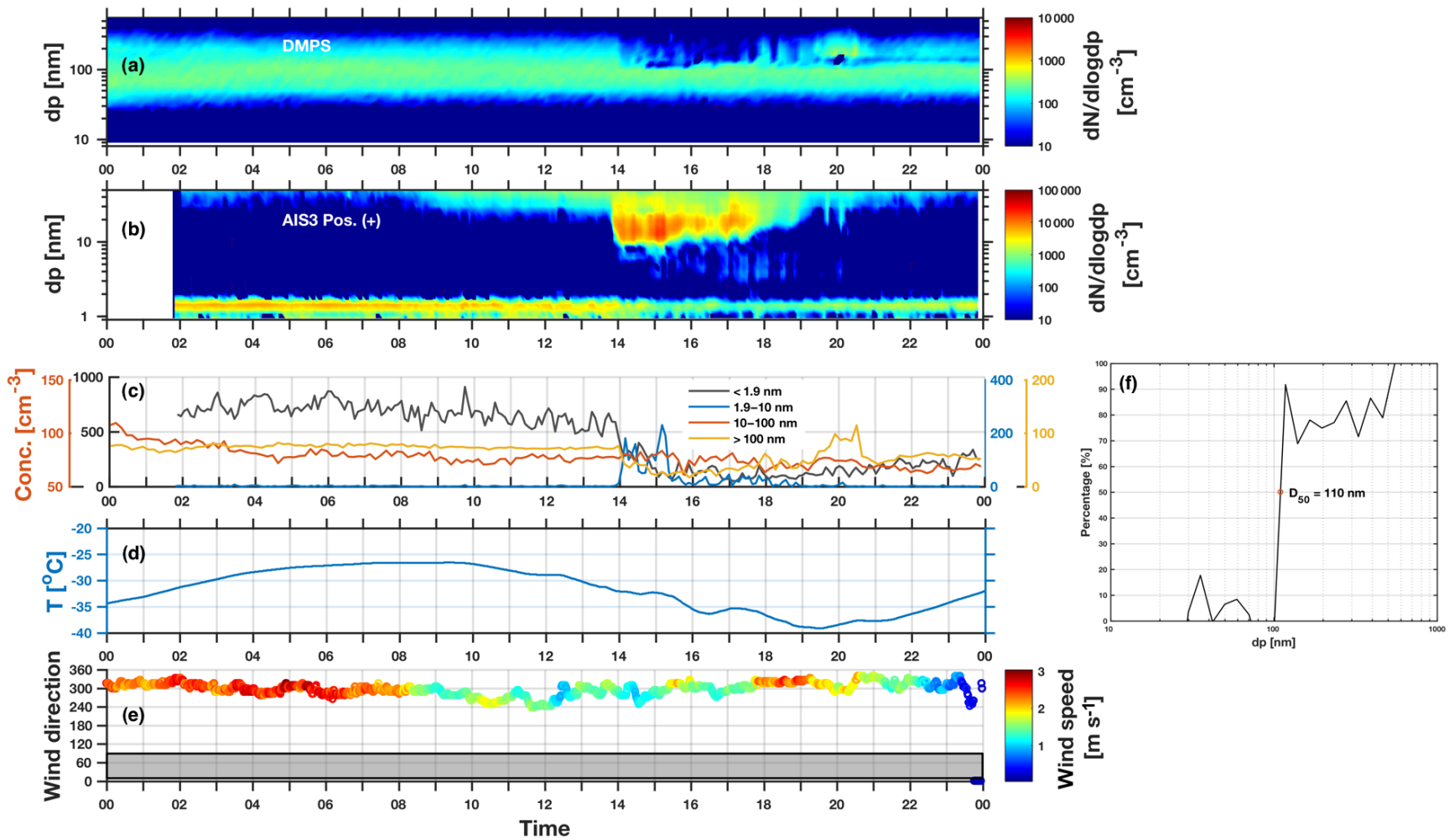

Figure 7. A cloud activation event observed on 20 January 2011. (a) DMPS spectra; (b) AIS positive polarity spectra; (c) ion and particle concentrations in four different size ranges: ions of diameters below $1.9 \mathrm{~nm}$, ions of diameters between 1.9 and $10 \mathrm{~nm}$, total particles of diameters between 10 and $100 \mathrm{~nm}$, and total particles of diameters above $100 \mathrm{~nm}$; (d) ambient air temperature (T); (e) wind direction, colourcoded with wind speed; and (f) activation diameter $\left(D_{50}\right)$, determined based on the method described by Komppula et al. (2005). Data are presented in UTC.

Table 1. GRs estimated from linear fittings with root-mean-square errors expressed as uncertainties for the nine growth modes shown in Fig. 5. $\mathrm{GR}_{\mathrm{mf}}$ stands for GRs determined by the mode-fitting method and $\mathrm{GR}_{\mathrm{apt}}$ for those determined by the appearance time method. Normal text in the table corresponds to GRs determined from the AIS measurement (9-12 March 2011) and bold text to GRs determined from the DMPS measurement (25 February, 2011).

\begin{tabular}{lrrrrrrrrr}
\hline $\mathrm{ID}$ & $\mathrm{GR}_{1}$ & $\mathrm{GR}_{2}$ & $\mathrm{GR}_{3}$ & $\mathrm{GR}_{4}$ & $\mathrm{GR}_{5}$ & $\mathrm{GR}_{6}$ & $\mathrm{GR}_{7}$ & $\mathbf{G R}_{\mathbf{8}}$ & $\mathbf{G R}_{9}$ \\
\hline $\mathrm{GR}_{\mathrm{mf}}\left(\mathrm{nm} \mathrm{h}^{-1}\right)$ & $1.4 \pm 2.2$ & $0.4 \pm 0.7$ & $0.3 \pm 0.3$ & $0.3 \pm 0.3$ & $0.5 \pm 1.0$ & $0.9 \pm 0.3$ & $0.9 \pm 0.3$ & $\mathbf{0 . 5} \pm \mathbf{1 . 0}$ & $\mathbf{1 . 2} \pm \mathbf{0 . 7}$ \\
Size ranges $(\mathrm{nm})$ & $4.6-29$ & $1.5-10$ & $6.7-14$ & $1.4-4.7$ & $1.3-12$ & $1.3-8.6$ & $3.1-8.2$ & $\mathbf{1 . 7}-\mathbf{1 2}$ & $\mathbf{1 0}-\mathbf{1 7}$ \\
$\mathrm{GR}_{\text {apt }}\left(\mathrm{nm} \mathrm{h}^{-1}\right)$ & $1.3 \pm 1.2$ & $1.1 \pm 0.5$ & $1.1 \pm 0.8$ & $0.4 \pm 0.2$ & $1.1 \pm 0.5$ & $1.5 \pm 1.2$ & $3.5 \pm 1.0$ & $\mathbf{1 . 6} \pm \mathbf{7 . 5}$ & $\mathbf{3 . 3} \pm \mathbf{1 . 2}$ \\
Size ranges $(\mathrm{nm})$ & $5.3-31$ & $1.4-17$ & $7.1-17$ & $1.4-5.3$ & $1.3-20$ & $1.4-13$ & $1.3-13$ & $\mathbf{1 . 7}-\mathbf{1 7}$ & $\mathbf{1 1 - 2 0}$ \\
\hline
\end{tabular}

with a standard deviation of $0.020 \mathrm{~cm}^{-3} \mathrm{~s}^{-1}$. An estimation of uncertainties in $J_{2}^{+}$was made by assuming an underestimation of $15-30 \%$ in the AIS measurement (Wagner et al., 2016), an uncertainty of $\pm 10 \%$ in the DMPS measurement in the whole size range (Wiedensohler et al., 2012), an error of $\pm 1 \mathrm{C}$ in the temperature measurement, and $\pm 1 \mathrm{hPa}$ in the pressure measurement. We calculated the maximum and minimum estimates of $J_{2}^{+}$based on these assumptions and evaluated the deviations of $J_{2}^{+}$from the mean values of the maximum and minimum estimates. We found that this deviation was smaller than $0.005 \mathrm{~cm}^{-3} \mathrm{~s}^{-1}$ $\left(<0.020 \mathrm{~cm}^{-3} \mathrm{~s}^{-1}\right)$ for more than $80 \%(88 \%)$ of the values of $J_{2}^{+}$. Other characteristic values for $J_{2}^{+}$were as follows: $0.0005 \mathrm{~cm}^{-3} \mathrm{~s}^{-1}$ (minimum), $0.0024 \mathrm{~cm}^{-3} \mathrm{~s}^{-1}$ (first quartile), $0.0066 \mathrm{~cm}^{-3} \mathrm{~s}^{-1}$ (median), $0.015 \mathrm{~cm}^{-3} \mathrm{~s}^{-1}$ (third quartile), and $0.079 \mathrm{~cm}^{-3} \mathrm{~s}^{-1}$ (maximum). These ion formation rates are comparable to those reported for the SMEAR II station in Finland (Nieminen et al., 2011), as well as to those observed in several other sites in Europe (Manninen et al., 2010). 


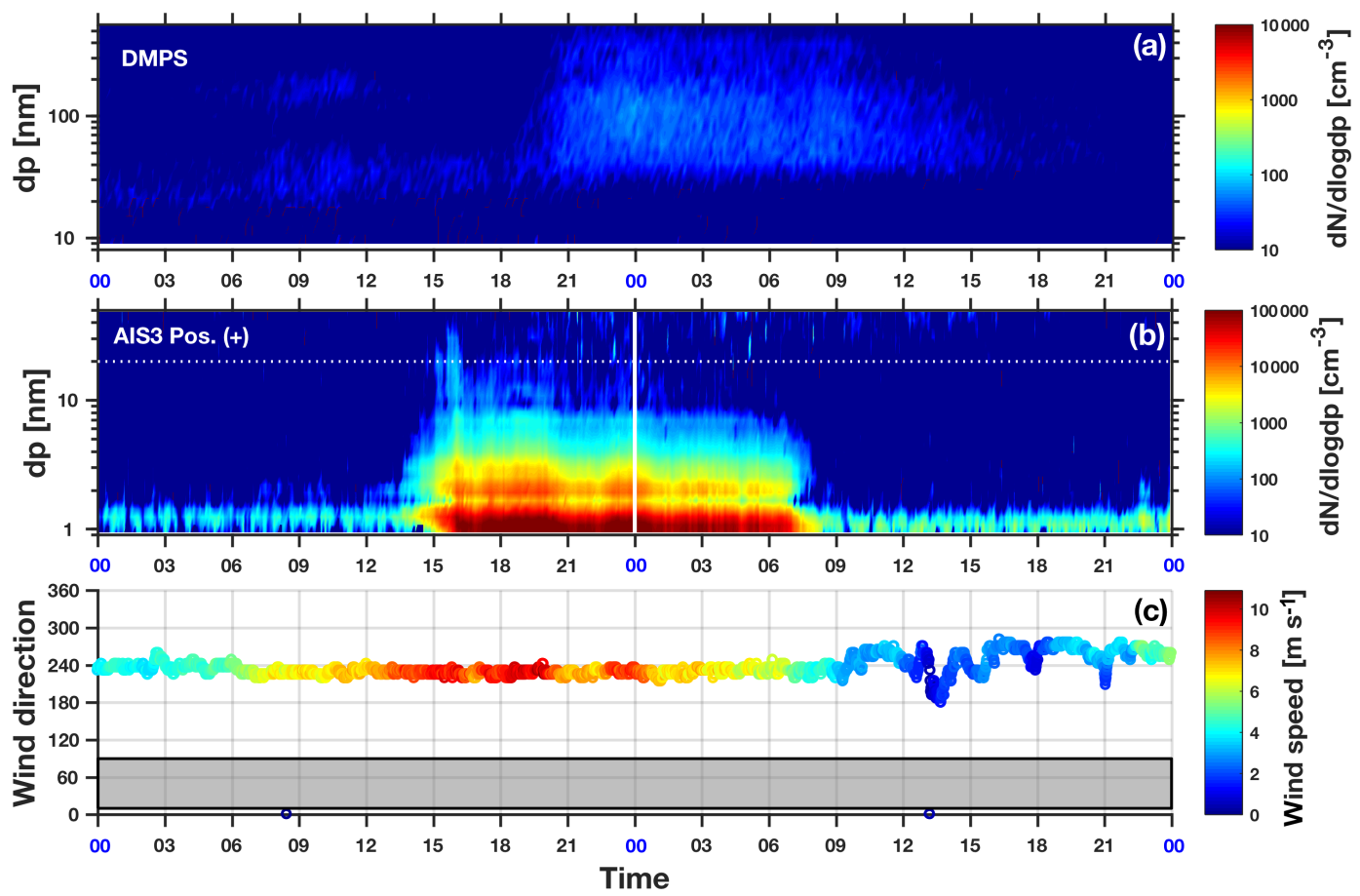

Figure 8. A wind-induced ion formation event observed on 3-4 July 2011. (a) DMPS spectra; (b) AIS positive polarity spectra; and (c) wind direction, colour-coded with wind speed. The white dotted line is a visual guide to outline the $20 \mathrm{~nm}$ location. The grey band in (c) represents the contaminated wind sector. Data are presented in UTC.

\subsection{Other specific features}

\subsubsection{Influence of cloud/fog formation on aerosol particles and air ions}

A cloud activation event initiated at around 14:00 UTC was observed on 20 January 2011 (Fig. 7). In general, such events are characterized by a disappearance of aerosol particles from the measured particle size range (Komppula et al., 2005; Kyrö et al., 2013). Additionally, a sudden drop in the cluster ion concentration has been reported as a feature for cloud activation events (Lihavainen et al., 2007). We observed similar connections between cluster ions and cloud activation at Dome C (Fig. 7a-c). Moreover, we found that the cloud activation event was accompanied by a burst of ions in the $8-42 \mathrm{~nm}$ size range measured by the AIS (Fig. 7b and c), yet not captured by the DMPS.

By following the approach introduced by Komppula et al. (2005) based on DMPS measurements, it can be estimated that particles larger than about $110 \mathrm{~nm}$ in diameter had been activated into cloud droplets during this cloud event (Fig. 7). This observation is well in line with the activation thresholds from $<50 \mathrm{~nm}$ up to about $200-300 \mathrm{~nm}$ for the "dry" particle diameter observed in real atmospheric clouds (see Henning et al., 2002, and references therein; Anttila et al., 2009; Kyrö et al., 2013; Portin et al., 2014; Leaitch et al., 2016). Cluster ions were efficiently lost onto the cloud droplets at Dome C. Because of their large sizes beyond the detection capability of the DMPS, cloud droplets could collect multiple charges via the uptake of cluster ions, which might then be detected by the AIS as singly charged particles in the size range of $8-42 \mathrm{~nm}$. Additionally, these ions detected by the AIS might also be artificial products resulting from the cloud droplet cleavage inside the sampling line of the instrument, possibly related to the high sample flowrate and the low-temperature condition (Fig. 7d). This cloud activation was possibly a result of ground-level fog formation, as lidar observations showed no evidence of clouds above $40 \mathrm{~m}$ (Fig. S3a and b). A cloudy pattern appeared in the lidar spectra at the near-ground level after about 15:00 UTC (Fig. S3c and $\mathrm{d}$ ). This $1 \mathrm{~h}$ delay compared with the aerosol instruments may be related to the fact that aerosol particles/cloud droplets cannot be captured by the lidar unless the aerosol/cloud layer is optically thick enough. It is very likely that the groundlevel fog was initially very thin, yet observable with the DMPS system, and only later became thick enough for the lidar to capture it. The high depolarization indicates a high probability of the presence of ice particles. Some precipitation could be recognized (Fig. S3a and b), originating from cirrus clouds at heights between 2500 and $3000 \mathrm{~m}$ above ground between 16:00 and 18:00 UTC. Light precipitation might have reached the ground level after around 18:00 UTC (Fig. S3c and d), which perturbed the cloud activation and 

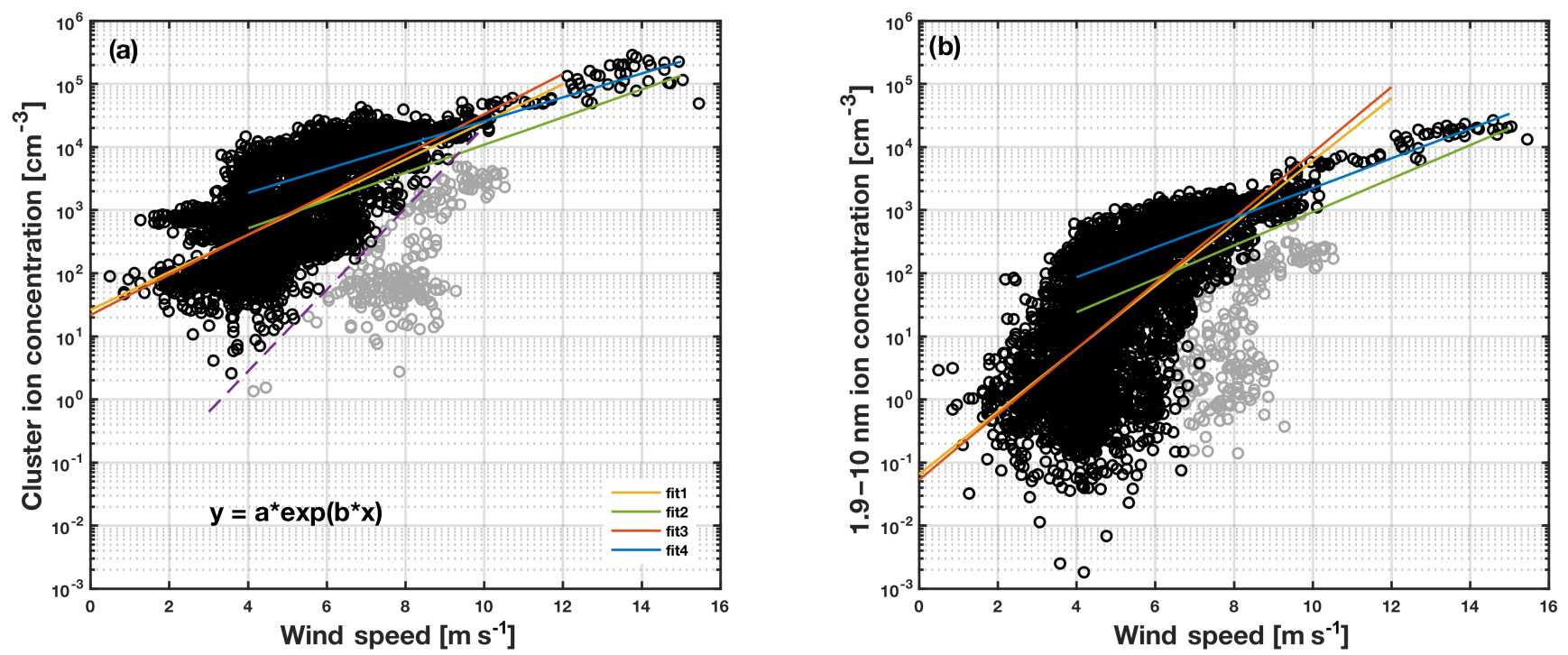

Figure 9. Ion concentrations as a function of wind speed: (a) ion concentration in the cluster size range (0.9-1.9 nm) and (b) ion concentration in the size range of 1.9-10 $\mathrm{nm}$. The solid lines are linear fits to the data. Fits 1 and 3 are to data with a wind speed below the threshold wind speed $\left(7 \mathrm{~m} \mathrm{~s}^{-1}\right)$ and fits 2 and 4 are to data above the threshold wind speed. Fits 1 and 2 are obtained based on all data below or above the wind speed threshold, respectively. The data points in grey colour, however, are not taken into account in determining the fitting coefficients for fits 3 and 4 . These grey data points correspond to cluster ion concentration values below the purple dashed line $\left(y=0.0074 \cdot e^{1.4855 x}\right)$. The coefficients of these fits as well as the $95 \%$ confidence bounds of the coefficients and coefficient of determination measuring the goodness of fit are given in Table S1 in the Supplement.

impaired the effect of fog/cloud formation exerted on air ions (Fig. 7a-c).

\subsubsection{Wind-induced ion formation}

Ion formation events during strong wind episodes have been observed at Aboa in Antarctica (Virkkula et al., 2007), as well as at the high-altitude site on Jungfraujoch in Switzerland (Manninen et al., 2010). At Dome C, we observed windinduced ion formation especially during the dark months (15 cases during May-August). An example of such an event, observed during 3-4 July 2011, illustrates the close connection between the ion formation and wind speed (Fig. 8): ions generated by a strong wind were mainly in the cluster ion size range, even though a large number of ions were also apparent in the $1.9-10 \mathrm{~nm}$ size range.

Under strong wind conditions, small snowflakes and ice crystals in the surface layer of the accumulated snow on the ground can be resuspended by turbulence and be shattered further by their collisions (Pomeroy and Jones, 1996). Vapours adsorbed on and trapped in these snowflakes and ice crystals can be released into the air to replenish vapours in the air that are capable of participating in cluster ion formation and possibly also NPF. This resuspension process also assists the escape of vapours trapped beneath the surface snow layer on the ground. Moreover, owing to the sudden drop of the surrounding vapour pressure, gaseous molecules of water and other trace species may also be freed from the resus- pended particles by sublimation (Pomeroy and Jones, 1996). Ionizing radiation produces primary ions, which are either lost through ion-ion recombination or transformed into more stable air ions by nucleation or condensation (Chen et al., 2016). A small concentration of ions slightly larger than the cluster sizes could be observed in connection to the high wind speeds between 06:00 and 12:00 UTC (Fig. 8b and c). As the wind speed increased further after 12:00 UTC, the vapour replenishment was probably amplified, leading to an ion burst in the size range of $0.9-10 \mathrm{~nm}$ via nucleation, condensation, and coagulation. A fraction of these ions seems to be able to further undergo dynamic processes to form large aerosol particles with sizes of even $500 \mathrm{~nm}$ (Fig. 8a).

Turbulent conditions might enhance the collection of electric charges by the shattered snowflakes and ice particles via a charge transfer from initial charge carriers, contributing to the formation of an ion burst. In addition, the shattered particles might gain electric charges through friction charging. However, we think that these two pathways of ion formation are not likely to contribute to the ion burst captured by the AIS. In principle, the shattering of resuspended snowflakes and ice particles mechanically by turbulence results in the formation of particles of smaller but random sizes. If this mechanism had produced nano-sized particles that subsequently became electrically charged either by charge transfer or friction charging, our AIS should have detected some of them and have shown an unsystematic spectrum, i.e. ions of random sizes and concentrations. Yet, conversely, the AIS 
showed high concentrations of ions of only small sizes, and hardly anything of sizes larger than $2-3 \mathrm{~nm}$ in diameter between 12:00 and 14:00 UTC during the intensification of the wind speed. Nevertheless, involvement of these processes cannot be ruled out completely based on our ambient observations. This kind of wind-induced ion formation warrants further experimental investigation, for example by releasing snow in a wind tunnel to disclose the true mechanisms governing the ion production.

Putting together all the 36 wind-induced ion formation events, the logarithm of the ion concentration exhibited linear relations to the wind speed (Fig. 9), as also observed at Aboa (Virkkula et al., 2007). For both cluster ions and ions in the size range of 1.9-10 nm, there seemed to be a two-step linear relation with a breakpoint at around $7 \mathrm{~m} \mathrm{~s}^{-1}$ (Fig. 9). Winds below this threshold value were less efficient in producing ions than winds with speeds of $>7 \mathrm{~m} \mathrm{~s}^{-1}$. This feature could be also recognized in the Aboa data, but with the threshold in wind speeds lying at around $17 \mathrm{~m} \mathrm{~s}^{-1}$ (Fig. S4). The effect of wind on ions seemed to be stronger at Dome $\mathrm{C}$ than at Aboa (Table S1 and Fig. S4). The slopes for the logarithm of ion concentrations as a function of wind speeds differed by about an order of magnitude between Dome C and Aboa. This is so far the clearest and largest difference in the air ion processes at these two sites and deserves a more detailed study in the future.

\section{Conclusions}

Based on 1 year of air ion observations with an AIS at Dome C, Antarctica, we found that this site has a rich set of ion processes, especially when considering its inland location on the largest ice desert on the Earth - the Antarctic Plateau. NPF, wind-induced ion formation, and ion production and loss associated with cloud/fog formation were the main processes that were found to modify the number size distribution of air ions at this high-altitude site. On event-free days, i.e. on days without the above-mentioned processes or other anomalies, concentrations of cluster ions $(0.9-1.9 \mathrm{~nm})$ showed a clear seasonality, with high concentrations in the warm months and low concentrations in the cold season. Days with NPF events were characterized by higher cluster ion concentrations than event-free days. The specific features of the recorded air ion data allowed further classification of NPF into suppressed NPF and multi-mode NPF events. The former refers to NPF events during which the growth of newly formed particles hardly exceeds $10 \mathrm{~nm}$, and the latter characterizes NPF events with two or three co-occurring NPF and growth events in different size ranges.

GRs determined using the mode-fitting method and appearance time method were used to characterize the NPF processes. Comparison between these two methods suggests that the GRs derived from the appearance time method work better in depicting the cases with a fast particle growth, whereas
GRs determined from the mode-fitting method appeared to be more suitable for describing cases with a slow particle growth. We found that the change in particle diameters did not usually increase linearly with the time. Therefore, we derived the instantaneous GR $(\mathrm{d} d p / \mathrm{d} t)$ as the change in sizes within the interval of two adjacent time stamps, and found that the GR tended to increase with an increasing particle size. The formation rate of $2 \mathrm{~nm}$ positive ions was found to be $0.014 \pm 0.020 \mathrm{~cm}^{-3} \mathrm{~s}^{-1}$ based on $26 \mathrm{NPF}$ events.

Ion production in relation to cloud/fog formation in the size range of $8-42 \mathrm{~nm}$ was found uniquely at Dome C. These ions may be either multiply charged particles detected as singly charged in the AIS or splinters of cloud droplets formed inside the instrument related to the instrumental behaviour under the extremely cold conditions. Accordingly, it would be worthwhile to carefully characterize the instrumental behaviour of ion spectrometers under extremely low temperature conditions in relation to the presence of cloud droplets by conducting laboratory experiments. In addition, wind-induced ion formation was found to resemble new aerosol particle formation from vapours released from the snow, rather than being caused by mechanical charging of shattered snowflakes or ice crystals. The ion formation during strong wind episodes is a phenomenon of great interest. It is also worth mentioning that at this high-plateau site, windinduced ion formation was approximately an order of magnitude stronger than at the low-altitude Antarctic site, Aboa, in which the same phenomenon has been observed earlier. The hidden mechanisms behind such processes need further investigation, which may reveal a new pathway of atmospheric NPF in dark wintertime conditions.

The air ion data used in this work were limited to the positive polarity due to a technical malfunctioning of the negative analyser. Further ambient measurements on air ions would be valuable to be carried out at Dome $\mathrm{C}$ and other sites on the Antarctic Plateau, not only to reveal possible differences between positive and negative ion properties and their connections to the ion and aerosol processes, but also to understand the mechanisms behind the ion formation related to the cloud/fog formation or wind episodes and to acquire a better characterization of atmospheric NPF in Antarctica. In the future in addition to air ions, the properties of neutral clusters and particles also need to be probed in order to understand the relative importance of ions and neutrals in atmospheric $\mathrm{NPF}$ at Dome C, and to characterize the comparability of the roles of ions and neutrals in atmospheric NPF observed at Dome $\mathrm{C}$ and at other sites around the globe.

Data availability. Data used in this work can be found via http://avaa.tdata.fi/openida/dl.jsp?pid=urn:nbn:fi:csc-ida.

\section{The Supplement related to this article is available online at https://doi.org/10.5194/acp-17-13783-2017- supplement.}


Competing interests. The authors declare that they have no conflict of interest.

Acknowledgements. This work received financial support from the Academy of Finland (project nos. 264375 and 264390), the NordForsk funded Nordic Centre of Excellence CRAICC (Cryosphere-atmosphere interactions in a changing Arctic climate, project no. 26060), and the Academy of Finland's Centre of Excellence Programme (Centre of Excellence in Atmospheric Science - From Molecular and Biological Processes to the Global Climate, project no. 272041). Funding for this research was also provided by Consiglio Nazionale delle Ricerche and PNRA (projects 2009/B.04 and 2010/A3.05). We appreciate the support of the IPEV/PNRA Project "Routine Meteorological Observation at Station Concordia", www.climantartide.it with the radiosounding data set. Xuemeng Chen acknowledges the Doctoral Programme in Atmospheric Sciences (ATM-DP, University of Helsinki) for financial support. Valuable advice from Sander Mirme is sincerely appreciated.

Edited by: Christopher Hoyle

Reviewed by: three anonymous referees

\section{References}

Aalto, P., Hämeri, K., Becker, E., Weber, R., Salm, J., MäKelä, J. M., Hoell, C., O'dowd, C. D., Karlsson, H., Hansson, H.-C., VäKevä, M., Koponen, I. K., Buzorius, G., and Kulmala, M.: Physical characterization of aerosol particles during nucleation events, Tellus B, 53, 344-358, 2001.

Anttila, T., Vaattovaara, P., Komppula, M., Hyvärinen, A.-P., Lihavainen, H., Kerminen, V.-M., and Laaksonen, A.: Sizedependent activation of aerosols into cloud droplets at a subarctic background site during the second Pallas Cloud Experiment (2nd PaCE): method development and data evaluation, Atmos. Chem. Phys., 9, 4841-4854, https://doi.org/10.5194/acp-9-48412009, 2009.

Asmi, E., Frey, A., Virkkula, A., Ehn, M., Manninen, H. E., Timonen, H., Tolonen-Kivimäki, O., Aurela, M., Hillamo, R., and Kulmala, M.: Hygroscopicity and chemical composition of Antarctic sub-micrometre aerosol particles and observations of new particle formation, Atmos. Chem. Phys., 10, 4253-4271, https://doi.org/10.5194/acp-10-4253-2010, 2010.

Augustin, L., Barbante, C., Barnes, P. R. F., Barnola, J. M., Bigler, M., Castellano, E., Cattani, O., Chappellaz, J., DahlJensen, D., Delmonte, B., Dreyfus, G., Durand, G., Falourd, S., Fischer, H., Flückiger, J., Hansson, M. E., Huybrechts, P., Jugie, G., Johnsen, S. J., Jouzel, J., Kaufmann, P., Kipfstuhl, J., Lambert, F., Lipenkov, V. Y., Littot, G. C., Longinelli, A., Lorrain, R., Maggi, V., Masson-Delmotte, V., Miller, H., Mulvaney, R., Oerlemans, J., Oerter, H., Orombelli, G., Parrenin, F., Peel, D. A., Petit, J.-R., Raynaud, D., Ritz, C., Ruth, U., Schwander, J., Siegenthaler, U., Souchez, R., Stauffer, B., Steffensen, J. P., Stenni, B., Stocker, T. F., Tabacco, I. E., Udisti, R., van de Wal, R. S. W., van den Broeke, M., Weiss, J., Wilhelms, F., Winther, J.-G., Wolff, E. W., and Zucchelli, M.: Eight glacial cycles from an Antarctic ice core, Nature, 429, 623-628, 2004.
Bazilevskaya, G. A., Usoskin, I. G., Flückiger, E. O., Harrison, R. G., Desorgher, L., Bütikofer, R., Krainev, M. B., Makhmutov, V. S., Stozhkov, Y. I., Svirzhevskaya, A. K., Svirzhevsky, N. S., and Kovaltsov, G. A.: Cosmic ray induced ion production in the atmosphere, Space Sci. Rev., 137, 149-173, https://doi.org/10.1007/s11214-008-9339-y, 2008.

Becagli, S., Scarchilli, C., Traversi, R., Dayan, U., Severi, M., Frosini, D., Vitale, V., Mazzola, M., Lupi, A., Nava, S., and Udisti, R.: Study of present-day sources and transport processes affecting oxidised sulphur compounds in atmospheric aerosols at Dome C (Antarctica) from yearround sampling campaigns, Atmos. Environ., 52, 98-108, https://doi.org/10.1016/j.atmosenv.2011.07.053, 2012.

Belosi, F., Contini, D., Donateo, A., Santachiara, G., and Prodi, F.: Aerosol size distribution at Nansen Ice Sheet Antarctica, Atmos. Res., 107, 42-50, https://doi.org/10.1016/j.atmosres.2011.12.007, 2012.

Boucher, O., Randall, D., Artaxo, P., Bretherton, C., Feingold, G., Forster, P., Kerminen, V.-M., Kondo, Y., Liao, H., Lohmann, U., Rasch, P., Satheesh, S. K., Sherwood, S., Stevens, B., and Zhang, X. Y.: Clouds and Aerosols, in: Climate Change 2013: The Physical Science Basis. Contribution of Working Group I to the Fifth Assessment Report of the Intergovernmental Panel on Climate Change, edited by: Stocker, T. F., Qin, D., Plattner, G.-K., Tignor, M., Allen, S. K., Boschung, J., Nauels, A., Xia, Y., Bex, V., Midgley, P. M., Cambridge University Press, Cambridge, UK and New York, NY, USA, 2013.

Bricard, J., Billard, F., and Madelaine, G.: Formation and evolution of nuclei of condensation that appear in air initially free of aerosols, J. Geophys. Res., 73, 4487-4496, https://doi.org/10.1029/JB073i014p04487, 1968.

Carslaw, K. S., Lee, L. A., Reddington, C. L., Pringle, K. J., Rap, A., Forster, P. M., Mann, G. W., Spracklen, D. V., Woodhouse, M. T., Regayre, L. A., and Pierce, J. R.: Large contribution of natural aerosols to uncertainty in indirect forcing, Nature, 503, 67-71, https://doi.org/10.1038/nature12674, 2013.

Chen, X., Kerminen, V.-M., Paatero, J., Paasonen, P., Manninen, H. E., Nieminen, T., Petäjä, T., and Kulmala, M.: How do air ions reflect variations in ionising radiation in the lower atmosphere in a boreal forest?, Atmos. Chem. Phys., 16, 14297 14315, https://doi.org/10.5194/acp-16-14297-2016, 2016.

Dal Maso, M., Kulmala, M., Lehtinen, K. E. J., Mäkelä, J. M., Aalto, P., and O'Dowd, C. D.: Condensation and coagulation sinks and formation of nucleation mode particles in coastal and boreal forest boundary layers, J. Geophys. Res.-Atmos., 107, D19, https://doi.org/10.1029/2001jd001053, 2002.

Dal Maso, M., Kulmala, M., Riipinen, I., Wagner, R., Hussein, T., Aalto, P. P., and Lehtinen, K. E. J.: Formation and growth of fresh atmospheric aerosols: eight years of aerosol size distribution data from SMEAR II, Hyytiälä, Finland, Boreal Environ. Res., 10, 323-336, 2005.

Dunne, E. M., Gordon, H., Kürten, A., Almeida, J., Duplissy, J., Williamson, C., Ortega, I. K., Pringle, K. J., Adamov, A., Baltensperger, U., Barmet, P., Benduhn, F., Bianchi, F., Breitenlechner, M., Clarke, A., Curtius, J., Dommen, J., Donahue, N. M., Ehrhart, S., Flagan, R. C., Franchin, A., Guida, R., Hakala, J., Hansel, A., Heinritzi, M., Jokinen, T., Kangasluoma, J., Kirkby, J., Kulmala, M., Kupc, A., Lawler, M. J., Lehtipalo, K., Makhmutov, V., Mann, G., Mathot, S., Merikanto, J., 
Miettinen, P., Nenes, A., Onnela, A., Rap, A., Reddington, C. L. S., Riccobono, F., Richards, N. A. D., Rissanen, M. P., Rondo, L., Sarnela, N., Schobesberger, S., Sengupta, K., Simon, M., Sipilä, M., Smith, J. N., Stozkhov, Y., Tomé, A., Tröstl, J., Wagner, P. E., Wimmer, D., Winkler, P. M., Worsnop, D. R., and Carslaw, K. S.: Global atmospheric particle formation from CERN CLOUD measurements, Science, 354, 1119-1124, 2016.

Ehn, M., Thornton, J. A., Kleist, E., Sipila, M., Junninen, H., Pullinen, I., Springer, M., Rubach, F., Tillmann, R., Lee, B., Lopez-Hilfiker, F., Andres, S., Acir, I. H., Rissanen, M., Jokinen, T., Schobesberger, S., Kangasluoma, J., Kontkanen, J., Nieminen, T., Kurten, T., Nielsen, L. B., Jorgensen, S., Kjaergaard, H. G., Canagaratna, M., Maso, M. D., Berndt, T., Petaja, T., Wahner, A., Kerminen, V. M., Kulmala, M., Worsnop, D. R., Wildt, J., and Mentel, T. F.: A large source of low-volatility secondary organic aerosol, Nature, 506, 476-479, https://doi.org/10.1038/nature13032, 2014.

Fiebig, M., Hirdman, D., Lunder, C. R., Ogren, J. A., Solberg, S., Stohl, A., and Thompson, R. L.: Annual cycle of Antarctic baseline aerosol: controlled by photooxidationlimited aerosol formation, Atmos. Chem. Phys., 14, 3083-3093, https://doi.org/10.5194/acp-14-3083-2014, 2014.

Fuchs, N. and Sutugin, A.: Highly dispersed aerosol, in: Topics in Current Aerosol Research, edited by: Hidy, G., Brock, J., Pergamon, New York, 1971.

Goldhagen, P.: Overview of aircraft radiation exposure and recent er-2 measurements, Health Phys., 79, 526-544, 2000.

Gunn, R.: DIffusion charging of atmospheric droplets by ions, and the resulting combination coefficients, J. Meteorol., 11, 339-347, 1954.

Häkkinen, S. A. K., Manninen, H. E., Yli-Juuti, T., Merikanto, J., Kajos, M. K., Nieminen, T., D’Andrea, S. D., Asmi, A., Pierce, J. R., Kulmala, M., and Riipinen, I.: Semi-empirical parameterization of size-dependent atmospheric nanoparticle growth in continental environments, Atmos. Chem. Phys., 13, 7665-7682, https://doi.org/10.5194/acp-13-7665-2013, 2013.

Hara, K., Osada, K., Nishita-Hara, C., Yabuki, M., Hayashi, M., Yamanouchi, T., Wada, M., and Shiobara, M.: Seasonal features of ultrafine particle volatility in the coastal Antarctic troposphere, Atmos. Chem. Phys., 11, 9803-9812, https://doi.org/10.5194/acp-11-9803-2011, 2011.

Harrison, R. G. and Tammet, H.: Ions in the terrestrial atmosphere and other solar system atmospheres, Space Sci. Rev., 137, 107118, https://doi.org/10.1007/s11214-008-9356-x, 2008.

Henning, S., Weingartner, E., Schmidt, S., Wendisch, M., Gäggeler, H. W., and Baltensperger, U.: Size-dependent aerosol activation at the high-alpine siteJungfraujoch (3580 ma.s.1.), Tellus B, 54, 82-95, 2002.

Hinds, W. C.: Aerosol Technology: Properties, Behavior, and Measurement of Airborne Particles, 2 ed., Wiley-Interscience, New York, 1999.

Hirsikko, A., Bergman, T., Laakso, L., Dal Maso, M., Riipinen, I., Hõrrak, U., and Kulmala, M.: Identification and classification of the formation of intermediate ions measured in boreal forest, Atmos. Chem. Phys., 7, 201-210, https://doi.org/10.5194/acp-7201-2007, 2007.

Hirsikko, A., Nieminen, T., Gagné, S., Lehtipalo, K., Manninen, H. E., Ehn, M., Hõrrak, U., Kerminen, V.-M., Laakso, L., McMurry,
P. H., Mirme, A., Mirme, S., Petäjä, T., Tammet, H., Vakkari, V., Vana, M., and Kulmala, M.: Atmospheric ions and nucleation: a review of observations, Atmos. Chem. Phys., 11, 767798, https://doi.org/10.5194/acp-11-767-2011, 2011.

Hõrrak, U., Salm, J., and Tammet, H.: Bursts of intermediate ions in atmospheric air, J. Geophys. Res.-Atmos., 103, 13909-13915, https://doi.org/10.1029/97jd01570, 1998.

IceCube Collaboration: Seasonal Variations of High Energy Cosmic Ray Muons Observed by the IceCube Observatory as a Probe of Kaon/Pion Ratio, 32nd International Cosmic Ray Conference, Beijing, 2011.

Israël, H.: Atmospheric Electricity, Vol. I, Israel Program for Scientific Translations, Jerusalem, 1970.

Ito, T.: Size distribution of Antarctic submicron aerosols, Tellus, 45 B, 145-159, 1993.

Järvinen, E., Virkkula, A., Nieminen, T., Aalto, P. P., Asmi, E., Lanconelli, C., Busetto, M., Lupi, A., Schioppo, R., Vitale, V., Mazzola, M., Petäjä, T., Kerminen, V.-M., and Kulmala, M.: Seasonal cycle and modal structure of particle number size distribution at Dome C, Antarctica, Atmos. Chem. Phys., 13, 7473-7487, https://doi.org/10.5194/acp-13-7473-2013, 2013.

Kazil, J., Lovejoy, E. R., Barth, M. C., and O’Brien, K.: Aerosol nucleation over oceans and the role of galactic cosmic rays, Atmos. Chem. Phys., 6, 4905-4924, https://doi.org/10.5194/acp-6-49052006, 2006.

Kerminen, V.-M., Paramonov, M., Anttila, T., Riipinen, I., Fountoukis, C., Korhonen, H., Asmi, E., Laakso, L., Lihavainen, H., Swietlicki, E., Svenningsson, B., Asmi, A., Pandis, S. N., Kulmala, M., and Petäjä, T.: Cloud condensation nuclei production associated with atmospheric nucleation: a synthesis based on existing literature and new results, Atmos. Chem. Phys., 12, 1203712059, https://doi.org/10.5194/acp-12-12037-2012, 2012.

Komppula, M., Lihavainen, H., Kerminen, V.-M., Kulmala, M., and Viisanen, Y.: Measurements of cloud droplet activation of aerosol particles at a clean subarctic background site, J. Geophys. Res.Atmos., 110, D06204, https://doi.org/10.1029/2004jd005200, 2005.

Koponen, I. K., Virkkula, A., Hillamo, R., Kerminen, V.M., and Kulmala, M.: Number size distributions and concentrations of the continental summer aerosols in Queen Maud Land, Antarctica, J. Geophys. Res.-Atmos., 108, 4587, https://doi.org/10.1029/2003jd003614, 2003.

Kulmala, M. and Kerminen, V.-M.: On the formation and growth of atmospheric nanoparticles, Atmos. Res., 90, 132-150, https://doi.org/10.1016/j.atmosres.2008.01.005, 2008.

Kulmala, M., Maso, M. D., Mäkelä, J. M., L. Pirjola, Väkevä, M., P. Aalto, Miikkulainen, P., Hämeri, K., and O' Dowd, C. D.: On the formation, growth and composition of nucleation mode particles, Tellus B, 53, 479-490, 2001.

Kulmala, M., Vehkamäki, H., Petäjä, T., Dal Maso, M., Lauri, A., Kerminen, V. M., Birmili, W., and McMurry, P. H.: Formation and growth rates of ultrafine atmospheric particles: a review of observations, J. Aerosol Sci., 35, 143-176, https://doi.org/10.1016/j.jaerosci.2003.10.003, 2004.

Kulmala, M., Petaja, T., Nieminen, T., Sipila, M., Manninen, H. E., Lehtipalo, K., Maso, M. D., Aalto, P. P., Junninen, H., Paasonen, P., Riipinen, I., Lehtinen, K. E., Laaksonen, A., and Kerminen, V.-M.: Measurement of the nucleation 
of atmospheric aerosol particles, Nat. Protoc., 7, 1651-1667, https://doi.org/10.1038/nprot.2012.091, 2012.

Kulmala, M., Kontkanen, J., Junninen, H., Lehtipalo, K., Manninen, H. E., Nieminen, T., Petaja, T., Sipila, M., Schobesberger, S., Rantala, P., Franchin, A., Jokinen, T., Jarvinen, E., Aijala, M., Kangasluoma, J., Hakala, J., Aalto, P. P., Paasonen, P., Mikkila, J., Vanhanen, J., Aalto, J., Hakola, H., Makkonen, U., Ruuskanen, T., Mauldin, R. L., 3rd, Duplissy, J., Vehkamaki, H., Back, J., Kortelainen, A., Riipinen, I., Kurten, T., Johnston, M. V., Smith, J. N., Ehn, M., Mentel, T. F., Lehtinen, K. E., Laaksonen, A., Kerminen, V.-M., and Worsnop, D. R.: Direct observations of atmospheric aerosol nucleation, Science, 339, $943-$ 946, https://doi.org/10.1126/science.1227385, 2013.

Kulmala, M., Petaja, T., Ehn, M., Thornton, J., Sipila, M., Worsnop, D. R., and Kerminen, V. M.: Chemistry of atmospheric nucleation: on the recent advances on precursor characterization and atmospheric cluster composition in connection with atmospheric new particle formation, Annu. Rev. Phys. Chem., 65, 21-37, https://doi.org/10.1146/annurev-physchem-040412$110014,2014$.

Kyrö, E.-M., Kerminen, V.-M., Virkkula, A., Dal Maso, M., Parshintsev, J., Ruíz-Jimenez, J., Forsström, L., Manninen, H. E., Riekkola, M.-L., Heinonen, P., and Kulmala, M.: Antarctic new particle formation from continental biogenic precursors, Atmos. Chem. Phys., 13, 3527-3546, https://doi.org/10.5194/acp13-3527-2013, 2013.

Leaitch, W. R., Korolev, A., Aliabadi, A. A., Burkart, J., Willis, M. D., Abbatt, J. P. D., Bozem, H., Hoor, P., Köllner, F., Schneider, J., Herber, A., Konrad, C., and Brauner, R.: Effects of $20-100 \mathrm{~nm}$ particles on liquid clouds in the clean summertime Arctic, Atmos. Chem. Phys., 16, 11107-11124, https://doi.org/10.5194/acp-16-11107-2016, 2016.

Lehtipalo, K., Leppä, J., Kontkanen, J., Kangasluoma, J., Franchin, A., Wimmer, D., Schobesberger, S., Junninen, H., Petäjä, T., Sipilä, M., Mikkilä, J., Vanhanen, J., Worsnop, D. R., and Kulmala, M.: Methods for determining particle size distribution and growth rates between 1 and $3 \mathrm{~nm}$ using the Particle Size Magnifier, Boreal Environ. Res., 19 (suppl. B), 215-236, 2014.

Leino, K., Nieminen, T., Manninen, H. E., Petäjä, T., Kerminen, V.M., and Kulmala, M.: Intermediate ions as a strong indicator of new particle formation bursts in a boreal forest, Boreal Environ. Res., 21, 274-286, 2016.

Lihavainen, H., Komppula, M., Kerminen, V.-M., Järvinen, H., Viisanen, Y., Lehtinen, K., Vana, M., and Kulmala, M.: Size distributions of atmospheric ions inside clouds and in cloud-free air at a remote continental site, Boreal Environ. Res., 12, 337-344, 2007.

Manninen, H. E., Petäjä, T., Asmi, E., Riipinen, I., Niemnen, T., Mikkilä, J., Hõrrak, U., Mirme, A., Mirme, S., Laakso, L., Kerminen, V.-M., and Kulmala, M.: Long-time field measurements of charged and neutral clusters using Neutral cluster and Air Ion Spectrometer (NAIS), Boreal Environ. Res., 14, 591-605, 2009.

Manninen, H. E., Nieminen, T., Asmi, E., Gagné, S., Häkkinen, S., Lehtipalo, K., Aalto, P., Vana, M., Mirme, A., Mirme, S., Hõrrak, U., Plass-Dülmer, C., Stange, G., Kiss, G., Hoffer, A., Törő, N., Moerman, M., Henzing, B., de Leeuw, G., Brinkenberg, M., Kouvarakis, G. N., Bougiatioti, A., Mihalopoulos, N., O’Dowd, C., Ceburnis, D., Arneth, A., Svenningsson, B., Swietlicki, E., Tarozzi, L., Decesari, S., Facchini, M. C., Birmili, W.,
Sonntag, A., Wiedensohler, A., Boulon, J., Sellegri, K., Laj, P., Gysel, M., Bukowiecki, N., Weingartner, E., Wehrle, G., Laaksonen, A., Hamed, A., Joutsensaari, J., Petäjä, T., Kerminen, V.-M., and Kulmala, M.: EUCAARI ion spectrometer measurements at 12 European sites - analysis of new particle formation events, Atmos. Chem. Phys., 10, 7907-7927, https://doi.org/10.5194/acp10-7907-2010, 2010.

Mason, E. A. and McDaniel, E. W.: Transport Properties of Ions in Gases, John Wiley and Sons, New York, Chichester, Brisbane, Toronto, Singapore, 1988.

Mirme, A., Tamm, E., Mordas, G., Vana, M., Uin, H., Mirme, S., Bernotas, T., Laakso, L., Hirsikko, A., and Kulmala, M.: A widerange multi-channel Air Ion Spectrometer, Boreal Environ. Res., 12, 247-264, 2007.

Mirme, S., Mirme, A., Minikin, A., Petzold, A., Hõrrak, U., Kerminen, V.-M., and Kulmala, M.: Atmospheric sub-3 nm particles at high altitudes, Atmos. Chem. Phys., 10, 437-451, https://doi.org/10.5194/acp-10-437-2010, 2010.

Mirme, S. and Mirme, A.: The mathematical principles and design of the NAIS - a spectrometer for the measurement of cluster ion and nanometer aerosol size distributions, Atmos. Meas. Tech., 6, 1061-1071, https://doi.org/10.5194/amt-6-1061-2013, 2013.

Nieminen, T., Paasonen, P., Manninen, H. E., Sellegri, K., Kerminen, V.-M., and Kulmala, M.: Parameterization of ioninduced nucleation rates based on ambient observations, Atmos. Chem. Phys., 11, 3393-3402, https://doi.org/10.5194/acp11-3393-2011, 2011.

Pant, V., Siingh, D., and Kamra, A. K.: Size distribution of atmospheric aerosols at Maitri, Antarctica, Atmos. Environ., 45, 5138-5149, https://doi.org/10.1016/j.atmosenv.2011.06.028, 2011.

Park, J., Sakurai, H., Vollmers, K., and McMurry, P. H.: Aerosol size distributions measured at the South Pole during ISCAT, Atmos. Environ., 38, 5493-5500, https://doi.org/10.1016/j.atmosenv.2002.12.001, 2004.

Pirjola, L., Kulmala, M., Wilck, M., Bischoff, A., Stratmann, F., and Otto, E.: Formation of sulphuric acid aerosols and cloud condensation nuclei: an expression for significant nucleation and model comparison, J. Aerosol Sci., 30, 1079-1094, 1998.

Poling, B. R., Prausnitz, J. M., and O'Connell, J. P.: The Properties of Gas and Liquids, 5 ed., McGraw-Hill, New York, 2004.

Pomeroy, J. W. and Jones, H. G.: Wind-Blown Snow: Sublimation, Trransport and Changes to Polar Snow, Processes of Chemical Exchange between the Atmosphere and Polar Snow, NATO ASI Series, Berlin, 453-490, 1996.

Portin, H., Leskinen, A., Hao, L., Kortelainen, A., Miettinen, P., Jaatinen, A., Laaksonen, A., Lehtinen, K. E. J., Romakkaniemi, S., and Komppula, M.: The effect of local sources on particle size and chemical composition and their role in aerosol-cloud interactions at Puijo measurement station, Atmos. Chem. Phys., 14, 6021-6034, https://doi.org/10.5194/acp-14-6021-2014, 2014.

Poschl, U.: Atmospheric aerosols: composition, transformation, climate and health effects, Angew. Chem. Int. Edit., 44, 7520-7540, https://doi.org/10.1002/anie.200501122, 2005.

Samson, J. A., Barnard, S. C., Obremski, J. S., Riley, D. C., Black, J. J., and Hogan, A. W.: On the systematic variation In surface aerosol concentration at the South Pole, Atmos. Res., 25, 385-396, 1990. 
Tang, M. J., Cox, R. A., and Kalberer, M.: Compilation and evaluation of gas phase diffusion coefficients of reactive trace gases in the atmosphere: volume 1. Inorganic compounds, Atmos. Chem. Phys., 14, 9233-9247, https://doi.org/10.5194/acp14-9233-2014, 2014.

Tinsley, B. A.: The global atmospheric electric circuit and its effects on cloud microphysics, Rep. Prog. Phys., 71, 066801, https://doi.org/10.1088/0034-4885/71/6/066801, 2008.

Virkkula, A., Hirsikko, A., Vana, M., Aalto, P. P., Hillamo, R., and Kulmala, M.: Charged particle size distributions and analysis of particle formation events at the Finnish antarctic research station aboa, Boreal Environ. Res., 12, 397-408, 2007.

Wagner, R., Manninen, H. E., Franchin, A., Lehtipalo, K., Mirme, S., Steiner, G., Petäjä, T., and Kulmala, M.: On the accuracy of ion measurements using a Neutral cluster and Air Ion Spectrometer, Boreal Environ. Res., 21, 230-241, 2016.

Wang, Z., Wu, Z., Yue, D., Shang, D., Guo, S., Sun, J., Ding, A., Wang, L., Jiang, J., Guo, H., Gao, J., Cheung, H. C., Morawska, L., Keywood, M., and Hu, M.: New particle formation in China: current knowledge and further directions, Sci. Total Environ., 577, 258-266, https://doi.org/10.1016/j.scitotenv.2016.10.177, 2017.

Waring, M. S. and Siegel, J. A.: The effect of an ion generator on indoor air quality in a residential room, Indoor Air, 21, 267-276, https://doi.org/10.1111/j.1600-0668.2010.00696.x, 2011.

Weller, R., Minikin, A., Wagenbach, D., and Dreiling, V.: Characterization of the inter-annual, seasonal, and diurnal variations of condensation particle concentrations at Neumayer, Antarctica, Atmos. Chem. Phys., 11, 13243-13257, https://doi.org/10.5194/acp-11-13243-2011, 2011.

Weller, R., Schmidt, K., Teinilä, K., and Hillamo, R.: Natural new particle formation at the coastal Antarctic site Neumayer, Atmos. Chem. Phys., 15, 11399-11410, https://doi.org/10.5194/acp-1511399-2015, 2015.
Wiedensohler, A., Birmili, W., Nowak, A., Sonntag, A., Weinhold, K., Merkel, M., Wehner, B., Tuch, T., Pfeifer, S., Fiebig, M., Fjäraa, A. M., Asmi, E., Sellegri, K., Depuy, R., Venzac, H., Villani, P., Laj, P., Aalto, P., Ogren, J. A., Swietlicki, E., Williams, P., Roldin, P., Quincey, P., Hüglin, C., Fierz-Schmidhauser, R., Gysel, M., Weingartner, E., Riccobono, F., Santos, S., Grüning, C., Faloon, K., Beddows, D., Harrison, R., Monahan, C., Jennings, S. G., O’Dowd, C. D., Marinoni, A., Horn, H.-G., Keck, L., Jiang, J., Scheckman, J., McMurry, P. H., Deng, Z., Zhao, C. S., Moerman, M., Henzing, B., de Leeuw, G., Löschau, G., and Bastian, S.: Mobility particle size spectrometers: harmonization of technical standards and data structure to facilitate high quality long-term observations of atmospheric particle number size distributions, Atmos. Meas. Tech., 5, 657-685, https://doi.org/10.5194/amt-5-657-2012, 2012.

Wilson, C. T. R.: The electric field of a thundercloud and some of its effects, Proc. Phys. Soc. London, 37, 32D, https://doi.org/10.1088/1478-7814/37/1/314, 1924.

Yli-Juuti, T., Nieminen, T., Hirsikko, A., Aalto, P. P., Asmi, E., Hõrrak, U., Manninen, H. E., Patokoski, J., Dal Maso, M., Petäjä, T., Rinne, J., Kulmala, M., and Riipinen, I.: Growth rates of nucleation mode particles in Hyytiälä during 20032009: variation with particle size, season, data analysis method and ambient conditions, Atmos. Chem. Phys., 11, 12865-12886, https://doi.org/10.5194/acp-11-12865-2011, 2011.

Yu, F. and Turco, R.: Case studies of particle formation events observed in boreal forests: implications for nucleation mechanisms, Atmos. Chem. Phys., 8, 6085-6102, https://doi.org/10.5194/acp8-6085-2008, 2008. 